\title{
Landscape, soil, lithology, climate and permafrost control on dissolved carbon, major and trace elements in the Ob River, western Siberia
}

\author{
Iurii Kolesnichenko', Larisa G. Kolesnichenko ${ }^{1}$, Sergey N. Vorobyev ${ }^{1}$, Liudmila S. Shirokova ${ }^{2,3}$, \\ Igor P. Semiletov ${ }^{4,5,6,7}$, Oleg V. Dudarev ${ }^{4}$, Rostislav S. Vorobev ${ }^{1}$, Ulyana Shavrina ${ }^{1}$, Sergey N. \\ Kirpotin $^{1}$, and Oleg S. Pokrovsky ${ }^{1,2,3^{*}}$ \\ 1 BIO-GEO-CLIM Laboratory, Tomsk State University, Lenin pr., 36, Tomsk, Russia \\ 2 Geosciences and Environment Toulouse, UMR 5563 CNRS, 14 Avenue Edouard Belin 31400 Toulouse, \\ France \\ 3 N. Laverov Federal Center for Integrated Arctic Research, Russian Academy of Sciences, Arkhangelsk, \\ Russia \\ 4 Laboratory of Arctic Research, V.I. Il'ichev Pacific Oceanological Institute, Far Eastern Branch of Russian \\ Academy of Sciences, 43 Baltic street, Vladivostok, 690041, Russia \\ 5 Tomsk Polytechnic University, Tomsk, Russia \\ 6 Tomsk State University, Tomsk, Russia \\ ${ }^{7}$ Department of Chemistry, Moscow State University, Moscow, Russia \\ *Corresponding: oleg.pokrovsky@get.omp.eu
}

\begin{abstract}
In order to foresee possible changes in elementary composition of Arctic river waters, complex studies with extensive spatial coverage, including gradients in climate and landscape parameters, are needed. Here we used the unique position of the Ob River, draining through the vast partially frozen peatlands of western Siberia Lowland and encompassing a sizable gradient of climate, permafrost, vegetation, soils and Quaternary deposits, to assess a snap-shot (8-23 July 2016) concentration of all major and trace elements in the main stem $\sim \sim 3000 \mathrm{~km}$ transect from the Tom River confluence in the south to Salekhard in the north) and its 11 tributaries. During studied period, corresponding to the end of the spring flood-summer baseflow, there was a systematic decrease, from the south to the north, of Dissolved Inorganic Carbon (DIC), Specific Conductivity, Ca and some labile trace elements (Mo, $\mathrm{W}$ and $\mathrm{U}$ ). In contrast, Dissolved Organic Carbon (DOC), Fe, $\mathrm{P}$, divalent metals ( $\mathrm{Mn}, \mathrm{Ni}, \mathrm{Cu}, \mathrm{Co}, \mathrm{Pb}$ ) and low mobile trace elements ( $\mathrm{Y}, \mathrm{Nb}, \mathrm{REEs}, \mathrm{Ti}, \mathrm{Zr}, \mathrm{Hf}$ and $\mathrm{Th}$ ) sizably increased their concentration northward. The Irtysh River, the main Ob's tributary, delivered enhanced amount of $\mathrm{Cl}, \mathrm{SO}_{4}, \mathrm{Na}, \mathrm{K}$ but also DOC to the Ob River as the concentrations of these elements in the main stem increased 2 to 3 -fold after the confluence with Irtysh.

The observed latitudinal pattern in element concentrations can be explained by progressive disconnection of groundwaters from the main river and its tributaries due to a northward increase in the permafrost coverage. A northward increase in bog versus forest coverage and an increase in DOC and Fe export enhanced the mobilization of insoluble, low mobile elements which were present in organo-ferric colloids $(1 \mathrm{kDa}-0.45 \mu \mathrm{m})$ as confirmed by in-situ dialysis size fractionation procedure. The chemical composition of sampled mainstream and tributaries demonstrated significant $(\mathrm{p}<0.01)$ control of latitude of the sampling point, permafrost coverage, proportion of bogs, lakes, floodplain coverage, lacustrine and fluvio-glacial Quaternary deposits of the watershed. This impact was mostly visible on DOC, $\mathrm{Fe}, \mathrm{P}$, divalent metals $(\mathrm{Mn}, \mathrm{Co}, \mathrm{Ni}, \mathrm{Cu}, \mathrm{Pb}$ ), $\mathrm{Rb}$ and low mobile lithogenic trace elements ( $\mathrm{Al}, \mathrm{Ti}, \mathrm{Cr}, \mathrm{Y}, \mathrm{Zr}, \mathrm{Nb}$, REEs, Hf, Th). The $\mathrm{pH}$ and concentrations of soluble, highly mobile elements (DIC, $\mathrm{SO}_{4}, \mathrm{Ca}, \mathrm{Sr}, \mathrm{Ba}, \mathrm{Mo}, \mathrm{Sb}, \mathrm{W}, \mathrm{U}$ ) positively correlated with the proportion of forest, loesses, eluvial, eolian, and fluvial Quaternary deposits on the watershed. Consistent with these correlations, a Principal Component Analysis demonstrated two main factors explaining the variability of major and trace element concentration in the Ob River main stem and tributaries. The DOC, Fe, divalent metals and trivalent and tetravalent trace elements were presumably controlled by a northward increase in permafrost, floodplain, bogs, lakes and lacustrine
\end{abstract}


deposits on the watersheds. The DIC and labile alkaline-earth metals, oxyanions ( $\mathrm{Mo}, \mathrm{Sb}, \mathrm{W})$ and $\mathrm{U}$ were impacted by southward-dominating forest coverage, loesses, eluvial and fertile soils.

Assuming that climate warming in the WSL will lead to a northward shift of the forest and permafrost boundaries, a "substituting space for time" approach predicts an increase in concentration of DIC and labile major and trace elements and a decrease of the transport of DOC and low soluble trace metals in the form of colloids in the main stem of the Ob River. However, an unknown factor is the change in hydrochemistry of the largest southern tributary, the Irtysh River, which is impacted by permafrost-free steppe and forest-steppe zone. Overall, seasonally-resolved transect studies of large riverine systems of western Siberia are needed to assess the hydrochemical response of this environmentally-important territory to on-going climate change.

Keywords: river, forest, bog, permafrost, carbon, major ions, iron, colloids, trace element

\section{Introduction}

Studies on hydrochemistry of large Arctic rivers are at the forefront of climate warming research due to their high importance in carbon (C) and greenhouse gases (GHG) regulation at the planetary scale and their high vulnerability to on-going environmental changes [1,2]. Presently, researchers achieved rather good understanding of hydrological fluxes and river water hydrochemistry, including both suspended and particulate load, at the terminal (gauged) stations across the Arctic, thanks to systematic work of State Hydrological Surveys of main Artic countries [3], and more recently, concerted works of various international programs $[4,5,6,7,8,9]$. In contrast, the knowledge of spatial variations of major and trace components of the river water along the main stem of Arctic rivers and their tributaries, which is necessary for understanding the environmental controls and export mechanisms, remains rather limited.

The Ob River, which is the largest Arctic river in terms of its watershed area $\left(2,975,000 \mathrm{~km}^{2}\right)$, is an important vector of carbon, nutrients, major and trace element transfer to the Kara Sea [10,11]. It drains highly vulnerable discontinuous and sporadic permafrost $(20 \%$ in average), which is extremely rich in organic $\mathrm{C}(\mathrm{OC})$ due to the dominance of peat soils [12]. Most recent hydrological studies demonstrated that, over past 80 years, the Ob River discharge increased by ca $7.7 \%$ [13], at a rate of 384 and $173 \mathrm{~m}\left({ }^{3}\right) / \mathrm{s}\left(10\right.$ year( $\left.\left.{ }^{-1}\right)\right)$, in spring and winter respectively, which was linked to a rapid increase in both warming and wetting of the territory [14]. This, together with its unique geographical situation and landscape setting, render the Ob River watershed among the key targeting regions for biogeochemical studies in the Arctic [2]. Interestingly, that the number of publications per year on the Ob River increased from < 10 prior to 1995 to 10-20 in 1996-2014 and 50-80 over the past 6 years.

Several detailed studies of Dissolved Organic Carbon (DOC) and major elements were conducted at the terminal gauging station of the river, near the Salekhard city $[4,5,6]$. These included DOC time series observation by molecular-level techniques [15] and via remote sensing [16] and quantification of particulate organic matter export [7]. In contrast, spatial coverage of the river main stem and tributaries is rather low, with just a few studies of the dissolved carbon and related $\mathrm{CO}_{2}$ and $\mathrm{CH}_{4}$ emissions $[17,18]$ and one study of molecular composition of DOC [19]. Large amount of data are available from systematic State Rosgidromet monitoring of OC and major ions on four gauging stations of the Ob River (Salekhard, Belogor'e, Aleksandrovskoe and Kolpashevo) during 1970-2010 and measurements by Tomsk Politechnical University as summarized in ref. [20]. The OCcontrolled export of $\mathrm{Hg}$ by the $\mathrm{Ob}$ River is considered by $\mathrm{Mu}$ et al. [21] and Sonke et al. [22]. A snapshot study of ${ }^{137} \mathrm{Cs}$ was performed at the scale of the Ob Basin [23]. Much less is known about other major and trace elements, especially their variations among the tributaries.

An important feature of the Ob River basin is the dominance of wetlands and mires which contain huge amount of OC and provide sizable input of DOM and relevant metals such as Fe to the $\mathrm{Ob}$ River main stem and tributaries due to strong hydrological connectivity (i.e., [24, 25, 26]. As a result of this enhanced input of Fe and DOC to the Ob River, its waters are likely to contain high 
concentration of colloids. However, this aspect has never been tested for the Ob River, although organic and organo-mineral colloids can be important carriers of a number of trace elements as it is known in small rivers [27] and surface waters [28, 29] across the western Siberia.

The novelty of the present work is to acquire a snap-shot picture of DOC, major and trace elements (TE), including their colloidal forms, in the main stem and several tributaries of the $\mathrm{Ob}$ River, and to test, for the first time for this territory, a landscape control, including vegetation, type of soil and Quaternary deposits, on chemical composition of the river water. The latter becomes now possible due to significant progress in digitalizing the available vegetation, permafrost and climate maps of large territories that allows straightforward landscape-based interpretation of river water chemistry (see examples in ref. [30, 31,32]). In this study, we hypothesized a dominant control of bog and permafrost coverage on the concentrations of DOC, major and trace elements in the main stem. In particular, in accord with previous studies of small WSL rivers [10, 30, 31, 33, 34, 35, 36], we expected a northward increase in DOC and decrease in soluble alkaline-earth metals. In order to reveal the mechanisms of element transport in the Ob River and its tributaries, we assessed the colloidal and truly dissolved (low molecular weight) concentration of carbon, all major and trace elements in selected samples. We hypothesized drastic change in organic colloids after the confluence of the $\mathrm{Ob}$ and Irtysh rivers, following recent study of DOM pattern in the Ob River main stem [19]. We anticipate that acquiring this new knowledge on riverine major and trace elements over large climate, permafrost and vegetation gradient of the Ob River basin will allow empirical but straightforward prediction of future changes in river water chemistry, following a well-established substituting space for time approach.

\section{Study site and methods}

\subsection{The $\mathrm{Ob}$ River of the WSL and its sampling}

The Ob River, which delivers $15 \%$ of the total freshwater flow to the Arctic Ocean $\left(404 \mathrm{~km}^{3} \mathrm{y}^{-1}\right)$, combines the features of southern rivers, draining steppe and forest-steppe regions, via its longest tributary, the Irtysh River, and the western Siberia Lowland rivers draining through a mixture of forest and mires. Further in the north, the $\mathrm{Ob}$ River is influenced by permafrost peatlands. The largest tributary of the $\mathrm{Ob}$ River is Irtysh which drains a territory of $1,643,000 \mathrm{~km}^{2}$ and exhibit the annual discharge of $88.371 \mathrm{~km}^{3}$ which is $37.5 \%$ of that of the Ob River upstream their confluence at KhantyMansiisk. During the open water high flow period of 2016, the contribution of Irtysh amounted to $49 \%$ of the Ob River discharge upstream the confluence.

In this work, we used a ship ('OM-341' vessel, see ref. [19]) route sampling and collected 21 main stem water samples going from the north to the south between 8 July 2016 and 23 July 2016 (Fig. 1). We covered in total 2,952 $\mathrm{km}$ of the river length which encompassed a sizable gradient in the latitude (from $66.79{ }^{\circ} \mathrm{N}$ in the most northern site Salemal to $56.91{ }^{\circ} \mathrm{N}$ in the most southern site Kozjulyno, Table S1). In addition, 11 tributaries of the $\mathrm{Ob}$ River were collected. The summer of 2016 was rather cold $\left(-3.1^{\circ}\right.$ below normal (defined as prior to 2000) for July) and slightly humid (130\% of normal precipitation for July).

The river water was collected from the surface $(0.5 \mathrm{~m}$ depth) in the central part of the main stem or minimum $500 \mathrm{~m}$ upstream the tributary via a pre-cleaned polypropylene 1-L container and immediately filtered $(<0.45 \mu \mathrm{m}$ regenerated cellulose filter) using a pre-cleaned 250 -mL polysulfone Nalgene filter unit combined with a vacuum pump. First, $250 \mathrm{~mL}$ of MilliQ water was filtered and the first portion of the river water filtrate $(250 \mathrm{~mL})$ was discarded. There was no decrease in the rate of filtration for sampled volumes (typically less than $500 \mathrm{~mL}$ ) so we do not expect any artifacts linked to filter clogging.

In addition to traditional $0.45 \mu \mathrm{m}$ filtration, 10 selected samples of the main stem and tributaries were processed for $1 \mathrm{kDa}(\sim 0.0013 \mathrm{~nm})$ dialysis, allowing to quantify the nominal low molecular weight $(\mathrm{LMW}<1 \mathrm{kDa})$ and colloidal $(1 \mathrm{kDa}-0.45 \mu \mathrm{m})$ fractions. For this, large volumes of the river water were collected into thoroughly cleaned and rinsed 5-L plastic container via filtration through $20 \mu \mathrm{m}$ 
Nylon net, to avoid large particles, zooplankton and insects. Dialysis experiments were performed using 50-ml pre-cleaned dialysis bags placed in the river water during 3 to 5 days as described elsewhere $[28,37]$. The plastic container was kept in darkness at the temperature similar to that of the river water and gently agitated due to ship movement and manually. The stability of river water chemical composition during the full length of dialysis procedure was verified by comparison of dissolved $(<0.45 \mu \mathrm{m})$ concentrations of all solutes before and after the exposure; the difference did not exceed $10 \%$ (at $\mathrm{p}<0.01$ ). As such, even if some microbial activity could occur during dialysis, it did not modify the colloidal composition of the river water.

\subsection{Analytical techniques}

All filtered and dialysed samples were stored in the refrigerator 1 month prior the analyses. Major anion concentrations ( $\mathrm{Cl}$ - and $\mathrm{SO}_{4}{ }^{2-}$ ) were measured by ion chromatography (Dionex 2000i) with an uncertainty of $2 \%$. The dissolved organic carbon (DOC) and dissolved inorganic carbon (DIC) was determined using a Shimadzu TOC-VSCN Analyzer with an uncertainty of 3\% and a detection limit of $0.3 \mathrm{mg} / \mathrm{L}$ [38]. In samples with low DOC $(<10 \mathrm{mg} / \mathrm{L})$, the DIC was also analyzed via potentiometric alkalinity titration procedure with an uncertainty of $\pm 1 \%$ and a detection limit of $5 x$ $10^{-5} \mathrm{~mol} \mathrm{~L}^{-1}$; the difference with results of Shimadzu did not exceed $5 \%$.

Major and trace elements were measured by quadrupole ICP-MS (7500ce, Agilent Technologies). Indium and rhenium were used as internal standards at their concentrations of approximately $3 \mu \mathrm{g}$ $\mathrm{L}^{-1}$. The international geostandard SLRS-5 (Riverine Water Reference Material for Trace Metals certified by the National Research Council of Canada) was used to check the validity and reproducibility of each analysis (see ref. 37 for analytical details). There was good agreement between our replicated measurements of SLRS- 5 and the certified values (relative difference $<15 \%$ ). Elements lacking the certified values in the SLRS sample or those having high intrinsic uncertainty of measurements $(>20 \%$ ) are not discussed in this work (Be, Sn, Te). For all major and most trace elements, analyzed by ICP MS, the concentrations in the blanks were below analytical detection limits ( $\leq$ 0.1-1 ng/L for Cd, Ba, Y, Zr, Nb, REE, Hf, Pb, Th, U; 1 ng/L for Ga, Ge, Rb, Sr, Sb; 10 ng/L for Ti, $\mathrm{V}, \mathrm{Cr}, \mathrm{Mn}, \mathrm{Fe}, \mathrm{Co}, \mathrm{Ni}, \mathrm{Cu}, \mathrm{Zn}, \mathrm{As})$. Further details of analyses are provided elsewhere [27, 28, 31].

\subsection{Landscape parameters of tributaries and the main stem}

The landscape parameters of the 9 tributaries and 23 points of the $\mathrm{Ob}$ River main stem were determined by digitalizing available soil, vegetation, lithological, and geocryological maps (Figure 1, Table S2). The landscape and soil parameters were typified using United State Database of Soil Resources (http://egrpr.soil.msu.ru/); the borders were verified and corrected according to available Landsat images. The permafrost parameters of watershed were obtained from CRU grids data (19502016) and NCSCD data. The type of Quaternary deposits were taken from State Geological Map of Russia with a resolution of 1:1,000,000 (http://www.geolkarta.ru/).

The Pearson rank order correlation coefficient (Rs) $(p<0.05)$ was used to determine the relationship between each major and trace element concentrations and the latitude, climatic, lithological and landscape parameters of the watersheds. Further statistical treatment of element concentration drivers in river waters included a Principal Component Analysis with a variance estimation method and a scree test to minimize the number of governing factors. This analysis allowed to test the effect of various environmental parameters (landscape, soil, vegetation, permafrost and type of Quaternary deposits) of the watershed on spatial of riverine solutes in both the $\mathrm{Ob}$ River main stem and the tributaries. 


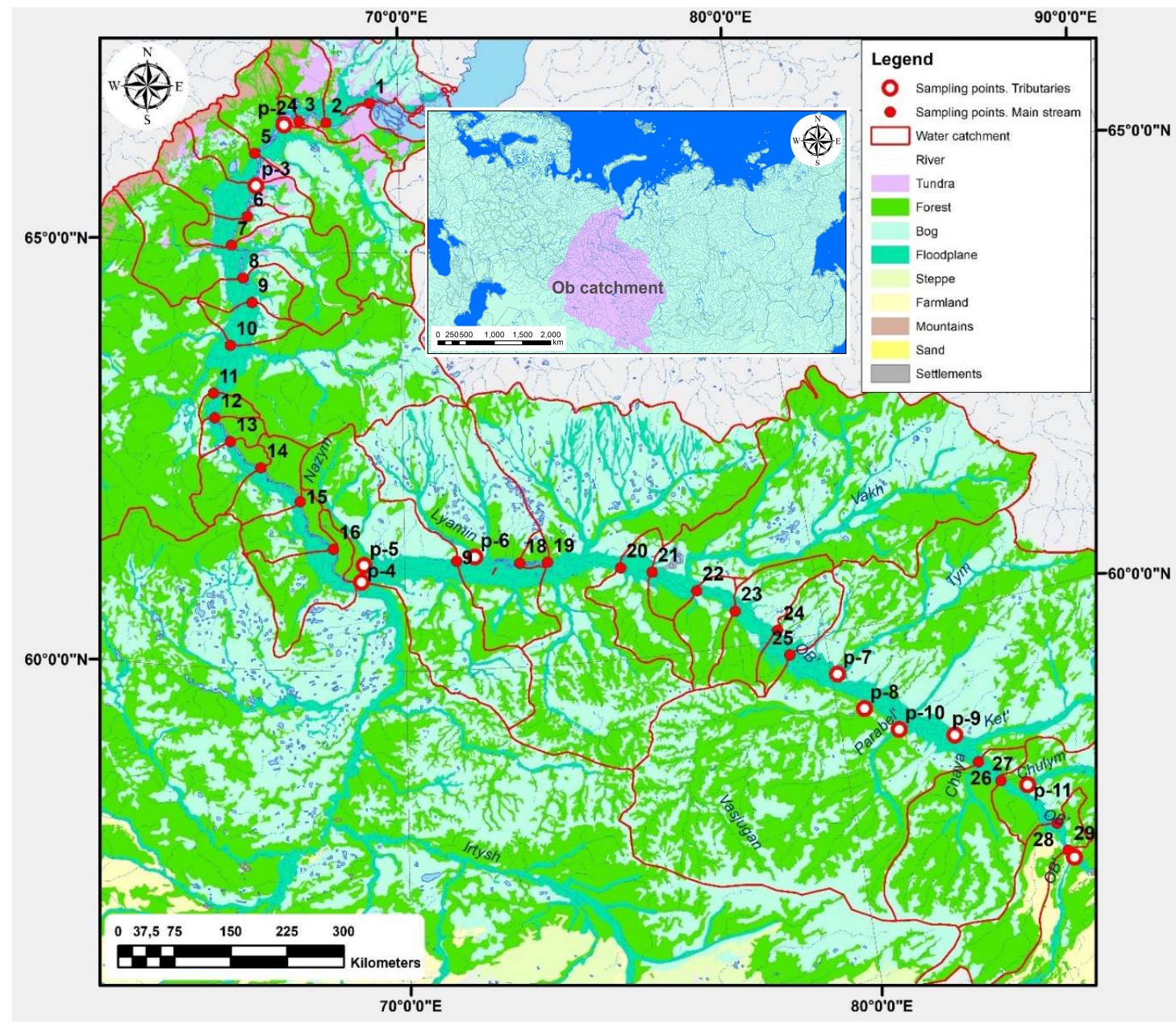

Fig 1. The Ob River and tributaries sampling points (solid and open circles, respectively) showing the dominant landscapes of the Ob River basin.

\section{Results}

\subsection{Impact of the latitude on element concentration in the main stem of the $\mathrm{Ob}$ River}

According to major and trace element behavior along the water course of the main stem [39], from the south to the north transect, three main families were distinguished as illustrated in Figures 2 and 3. Dissolved Inorganic Carbon, alkaline-earth metals (Ca, Sr), Mo, W, and U sizably (by a factor of 2.0) decreased their concentrations northward (Fig. 2). 

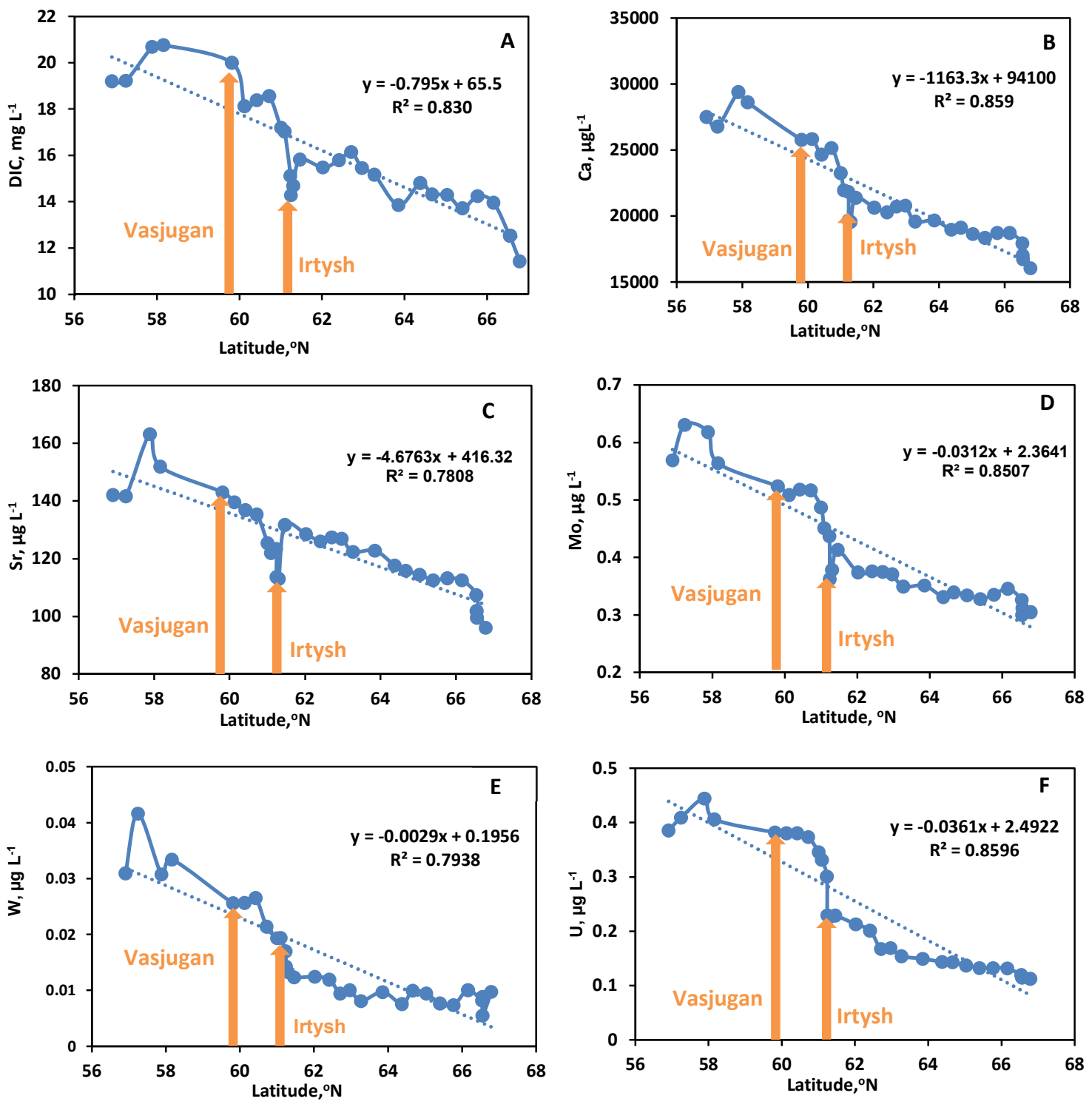

Figure 2. Latitudinal trends of labile major and trace elements decreasing their concentrations in the main stem of the Ob River from the south to the north: DIC (A), Ca (B), Sr (C), Mo(D), W (E) and U (F). The two main tributaries likely to control DOC and trace metal delivery, rivers Vasjugan and Irtysh, are shown by arrows.

The $2^{\text {nd }}$ group of elements included $\mathrm{DOC}, \mathrm{P}, \mathrm{Mn}, \mathrm{Al}, \mathrm{Fe}, \mathrm{Ti}, \mathrm{Ni}, \mathrm{Cu}, \mathrm{Co}, \mathrm{Rb}, \mathrm{Pb}, \mathrm{Y}, \mathrm{Zr}, \mathrm{Nb}, \mathrm{REE}, \mathrm{Hf}$ and Th which strongly (by a factor of 2 to 10) increased their concentration from the south to the north (Fig. 3). Sharp increase of these element concentration in the main stem of the Ob River occurred after the confluence first with Vasjugan, and then, Irtysh; the impact of Irtysh was especially seen for major anions $\left(\mathrm{Cl}, \mathrm{SO}_{4}\right)$ and alkali $(\mathrm{Na}, \mathrm{K})$, and $\mathrm{Pb}$ (Fig. $\mathrm{S} 1$ of the Supplement). Finally, a group of elements did not exhibit any sizable $(>1.5 \mathrm{x}$ ) change in concentration over the main stem $(\mathrm{Si}, \mathrm{Li}, \mathrm{V}, \mathrm{Ba})$ or the evolution of their concentration did not follow any specific pattern (B, $\mathrm{Mg}, \mathrm{Cr}, \mathrm{Zn}, \mathrm{Cd}, \mathrm{Ga}, \mathrm{Ge}, \mathrm{Cs}, \mathrm{Tl})$ as illustrated in Fig. S2. Note some peaks in concentrations detected for $\mathrm{Zn}, \mathrm{Cd}$ and $\mathrm{Pb}$ which can be tentatively linked to local pollution sources.

Because the Vasyugan River, draining the largest world mire [40], can substantially modify the $\mathrm{Ob}$ River chemical composition, the degree of element enrichment in the northern part of the Ob River (downstream of Irtysh) was compared to its intermediate part (between Vasyugan and Irtysh) and the 
southern part (between Tom and Vasyugan) was assessed via comparison of average concentrations in these three segments of the main stem (Table 1). It can be seen that the elements mostly enriched (by a factor of 2 to 10) in the northern part of the river are $\mathrm{DOC}, \mathrm{Cl}, \mathrm{P}, \mathrm{Mn}, \mathrm{Fe}$, some divalent metals ( $\mathrm{Mn}, \mathrm{Ni}, \mathrm{Pb}$ ) and insoluble lithogenic elements - $\mathrm{Al}, \mathrm{Ti}, \mathrm{Nb}, \mathrm{Y}, \mathrm{REE}, \mathrm{Ti}, \mathrm{Zr}, \mathrm{Hf}, \mathrm{Th}$ ).

Table 1. Mean $( \pm \mathrm{SD})$ concentration $\left(\mu \mathrm{g} \mathrm{L}^{-1}\right)$ of major and trace elements in in three distinct parts of the $\mathrm{Ob}$ River main stem upstream and downstream its confluence with Vasyugan and Irtysh.

\begin{tabular}{|c|c|c|c|}
\hline Descritions & Tom - Vasyugan $(n=4)$ & Vasyugan - Irtysh $(\mathrm{n}=11)$ & Irtysh - Salemal $(n=16)$ \\
\hline $\mathrm{Cl}$ & $1740 \pm 510$ & $1660 \pm 430$ & $7240 \pm 530$ \\
\hline $\mathrm{SO}_{4}$ & $7070 \pm 1340$ & $5106 \pm 888$ & $8480 \pm 392$ \\
\hline DOC & $4600 \pm 930$ & $7200 \pm 2100$ & $11500 \pm 400$ \\
\hline $\mathrm{UV}_{245^{*}}$ & $0.13 \pm 0.45$ & $0.28 \pm 0.12$ & $0.49 \pm 0.02$ \\
\hline DIC & $18500 \pm 5300$ & $16690 \pm 2180$ & $15100 \pm 766$ \\
\hline $\mathrm{Li}$ & $2.63 \pm 0.92$ & $1.91 \pm 0.17$ & $2.74 \pm 0.19$ \\
\hline $\mathrm{B}$ & $13.9 \pm 2.5$ & $10.0 \pm 0.63$ & $17.7 \pm 1.64$ \\
\hline $\mathrm{Na}$ & $5866 \pm 1471$ & $4533 \pm 296$ & $8635 \pm 566$ \\
\hline $\mathrm{Mg}$ & $5086 \pm 803$ & $4092 \pm 308$ & $4788 \pm 236$ \\
\hline $\mathrm{Al}$ & $6.84 \pm 1.96$ & $11.56 \pm 3.02$ & $18.67 \pm 2.28$ \\
\hline $\mathrm{Si}$ & $2987 \pm 934$ & $2905 \pm 797$ & $2440 \pm 75$ \\
\hline $\mathrm{P}$ & $30.7 \pm 14.7$ & $49.030 \pm 19.5$ & $75.4 \pm 5.7$ \\
\hline $\mathrm{K}$ & $1115 \pm 183$ & $972 \pm 137$ & $1571 \pm 98$ \\
\hline $\mathrm{Ca}$ & $29664 \pm 3822$ & $22677 \pm 2683$ & $19978 \pm 914$ \\
\hline $\mathrm{Ti}$ & $3.27 \pm 1.20$ & $5.46 \pm 1.84$ & $8.80 \pm 1.04$ \\
\hline $\mathrm{V}$ & $1.67 \pm 0.3$ & $1.37 \pm 0.08$ & $1.52 \pm 0.03$ \\
\hline $\mathrm{Cr}$ & $0.14 \pm 0.11$ & $0.27 \pm 0.12$ & $0.30 \pm 0.12$ \\
\hline $\mathrm{Mn}$ & $2.0 \pm 1.48$ & $18.0 \pm 49.0$ & $4.5 \pm 0.5$ \\
\hline $\mathrm{Fe}$ & $59 \pm 62$ & $440 \pm 475$ & $664 \pm 58$ \\
\hline $\mathrm{Co}$ & $0.04 \pm 0.02$ & $0.07 \pm 0.1$ & $0.07 \pm 0.01$ \\
\hline $\mathrm{Ni}$ & $0.6 \pm 0.2$ & $0.9 \pm 0.5$ & $1.9 \pm 0.1$ \\
\hline $\mathrm{Cu}$ & $1.7 \pm 0.5$ & $1.7 \pm 0.2$ & $2.3 \pm 0.2$ \\
\hline $\mathrm{Zn}$ & $4.8 \pm 3.2$ & $3.0 \pm 1.5$ & $5.5 \pm 3.2$ \\
\hline $\mathrm{Ga}$ & $0.01 \pm 0.004$ & $0.01 \pm 0.002$ & $0.01 \pm 0.002$ \\
\hline $\mathrm{Ge}$ & $0.01 \pm 0.003$ & $0.007 \pm 0.002$ & $0.009 \pm 0.001$ \\
\hline As & $1.4 \pm 0.2$ & $1.3 \pm 0.5$ & $1.5 \pm 0.07$ \\
\hline $\mathrm{Rb}$ & $0.6 \pm 0.09$ & $0.8 \pm 0.5$ & $1.2 \pm 0.09$ \\
\hline $\mathrm{Sr}$ & $165 \pm 33$ & $126 \pm 13$ & $123 \pm 6$ \\
\hline $\mathrm{Y}$ & $0.04 \pm 0.03$ & $0.1 \pm 0.05$ & $0.3 \pm 0.01$ \\
\hline $\mathrm{Zr}$ & $0.02 \pm 0.02$ & $0.06 \pm 0.03$ & $0.1 \pm 0.01$ \\
\hline $\mathrm{Nb}$ & $0.002 \pm 0.002$ & $0.007 \pm 0.005$ & $0.02 \pm 0.002$ \\
\hline Mo & $0.7 \pm 0.08$ & $0.4 \pm 0.1$ & $0.4 \pm 0.03$ \\
\hline $\mathrm{Cd}$ & $0.01 \pm 0.01$ & $0.009 \pm 0.009$ & $0.01 \pm 0.006$ \\
\hline $\mathrm{Sb}$ & $0.1 \pm 0.02$ & $0.1 \pm 0.02$ & $0.09 \pm 0.004$ \\
\hline
\end{tabular}




\begin{tabular}{|c|c|c|c|}
\hline Descritions & Tom - Vasyugan $(n=4)$ & Vasyugan - Irtysh $(\mathrm{n}=11)$ & Irtysh - Salemal $(n=16)$ \\
\hline Cs & $0.001 \pm 0.00$ & $0.001 \pm 0.000$ & $0.002 \pm 0.000$ \\
\hline $\mathrm{Ba}$ & $24 \pm 3$ & $22 \pm 0.9$ & $24 \pm 0.7$ \\
\hline $\mathrm{La}$ & $0.03 \pm 0.02$ & $0.1 \pm 0.04$ & $0.2 \pm 0.01$ \\
\hline $\mathrm{Ce}$ & $0.04 \pm 0.03$ & $0.2 \pm 0.08$ & $0.4 \pm 0.02$ \\
\hline $\operatorname{Pr}$ & $0.01 \pm 0.01$ & $0.03 \pm 0.01$ & $0.06 \pm 0.003$ \\
\hline $\mathrm{Nd}$ & $0.03 \pm 0.03$ & $0.1 \pm 0.04$ & $0.2 \pm 0.02$ \\
\hline $\mathrm{Sm}$ & $0.01 \pm 0.01$ & $0.03 \pm 0.01$ & $0.06 \pm 0.004$ \\
\hline $\mathrm{Eu}$ & $0.004 \pm 0.002$ & $0.008 \pm 0.002$ & $0.015 \pm 0.001$ \\
\hline Gd & $0.01 \pm 0.01$ & $0.03 \pm 0.01$ & $0.06 \pm 0.004$ \\
\hline $\mathrm{Tb}$ & $0.001 \pm 0.001$ & $0.004 \pm 0.001$ & $0.008 \pm 0.000$ \\
\hline Dy & $0.006 \pm 0.004$ & $0.02 \pm 0.008$ & $0.05 \pm 0.003$ \\
\hline Ho & $0.001 \pm 0.001$ & $0.004 \pm 0.002$ & $0.009 \pm 0.001$ \\
\hline $\mathrm{Er}$ & $0.004 \pm 0.003$ & $0.01 \pm 0.004$ & $0.03 \pm 0.002$ \\
\hline $\mathrm{Tm}$ & $0.000 \pm 0.000$ & $0.002 \pm 0.001$ & $0.004 \pm 0.000$ \\
\hline $\mathrm{Yb}$ & $0.003 \pm 0.002$ & $0.01 \pm 0.004$ & $0.02 \pm 0.002$ \\
\hline $\mathrm{Lu}$ & $0.000 \pm 0.000$ & $0.002 \pm 0.001$ & $0.003 \pm 0.000$ \\
\hline Hf & $0.002 \pm 0.001$ & $0.008 \pm 0.004$ & $0.02 \pm 0.002$ \\
\hline $\mathrm{W}$ & $0.03 \pm 0.01$ & $0.02 \pm 0.007$ & $0.01 \pm 0.002$ \\
\hline $\mathrm{Tl}$ & $0.002 \pm 0.001$ & $0.001 \pm 0.000$ & $0.002 \pm 0.000$ \\
\hline $\mathrm{Pb}$ & $0.07 \pm 0.1$ & $0.2 \pm 0.1$ & $0.2 \pm 0.02$ \\
\hline Th & $0.001 \pm 0.001$ & $0.007 \pm 0.004$ & $0.02 \pm 0.002$ \\
\hline $\mathrm{U}$ & $0.4 \pm 0.06$ & $0.3 \pm 0.1$ & $0.2 \pm 0.03$ \\
\hline
\end{tabular}



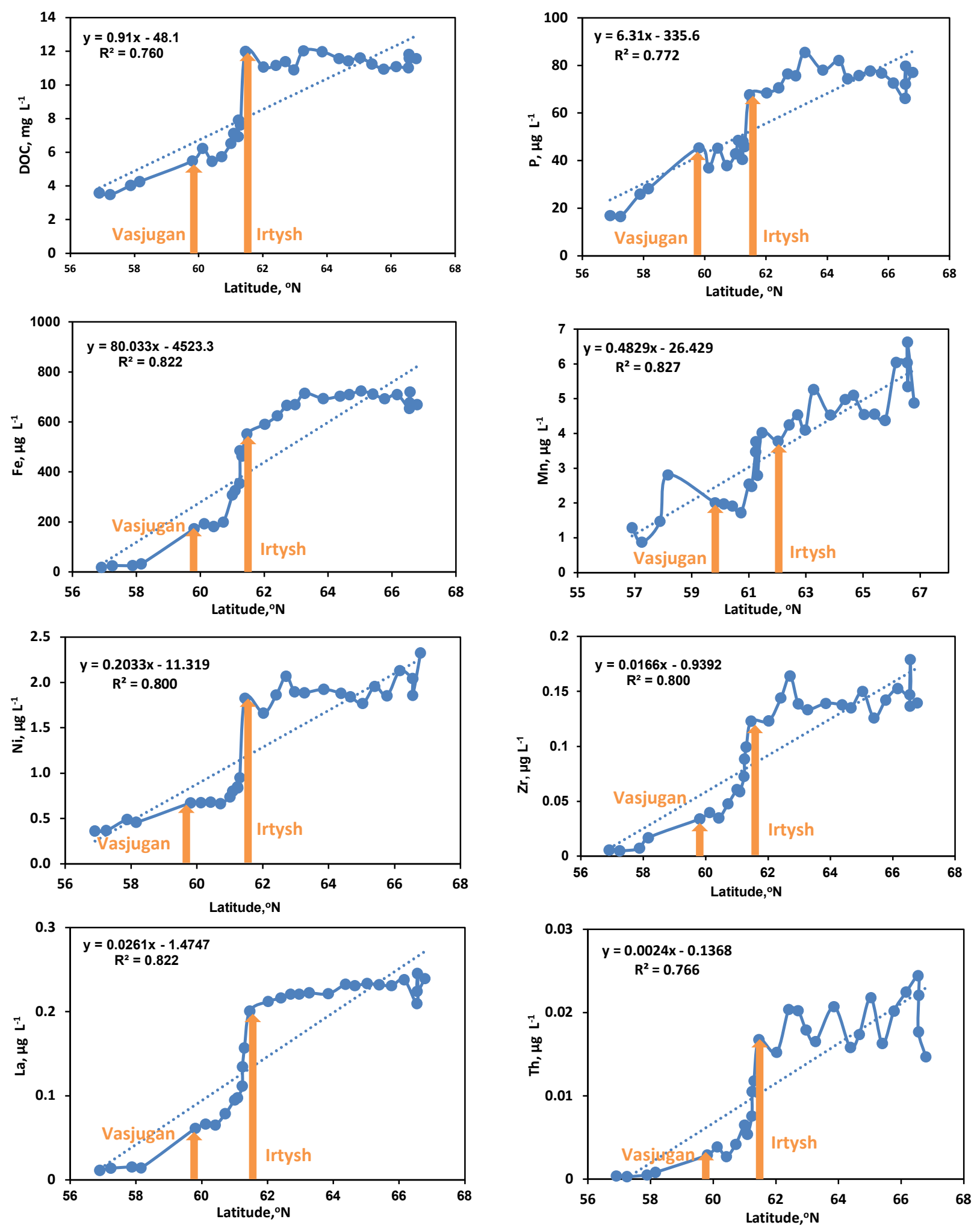

Figure 3. Latitudinal trends of DOC, nutrients $(\mathrm{P}, \mathrm{Fe}, \mathrm{Mn}, \mathrm{Ni})$ and insoluble trace elements $(\mathrm{Zr}, \mathrm{La}, \mathrm{Th})$ showing strong increase in concentration in the $\mathrm{Ob}$ main stem after the confluence with the Vasyugan and Irtysh River (shown by arrows). 
The distinction of riverine solutes into three major groups depending on their latitudinal pattern was also confirmed by a Pearson correlation coefficients between the element concentration and the latitude (Table S3 of the Supplement). The elements of the first group exhibited quite strong $(\leq-0.90$, $\mathrm{p}<0.005)$ negative correlations with latitude, whereas the elements of second group had Rearson $>$ 0.80 . The elements with weak or non-systematic pattern showed statistically significant correlations $(\mathrm{p}<0.05)$ but the $\mid$ Rearson $\mid$ was typically below 0.8 .

\subsection{Major and trace elements in the tributaries}

The 11 tributaries sampled in this study exhibited highly contrasting behavior in both major and trace element concentrations. Similar to the main stem, this allowed revealing distinct group of elements according to their latitudinal pattern. The southern tributaries (upstream of Irtysh) were enriched in DIC, major anions, alkali and alkaline-earth metals and U, whereas the northern tributaries exhibited much higher concentrations of $\mathrm{Mn}, \mathrm{Fe}, \mathrm{Co}$ ( $>5$ times) and were sizably enriched in DOC, Cr, P, Zn, Cd, Nb, trivalent and tetravalent low soluble trace elements (Fig. S3).

The Irtysh River played a governing role in the concentration pattern of the main stem, as it presented sizable addition of many elements, mostly labile anions and oxyanions (DIC, $\mathrm{Cl}, \mathrm{SO}_{4}, \mathrm{~B}$, $\mathrm{Mo}, \mathrm{Sb}, \mathrm{W})$, alkalis and alkaline-earth metals ( $\mathrm{Li}, \mathrm{Na}, \mathrm{K}, \mathrm{Rb}, \mathrm{Mg}, \mathrm{Ca}, \mathrm{Sr}, \mathrm{Ba}$ ), some divalent transition metals (Mn, Co, Ni), U and DOC to the main stem, given its high discharge (49\% of the Ob River at the confluence in 2016) and most importantly, elevated concentration of elements (Fig. 4). Some elements however, exhibited higher concentration in the northern part of the Ob River compared to the Irtysh River: Al, Fe, Cr, Zn, Ga, Nb, Ti, Zr, Hf, REEs (Fig. 4). Presumably, these elements are additionally delivered to the $\mathrm{Ob}$ River main stem via multiple small-size tributaries, which were not sampled in the present work.

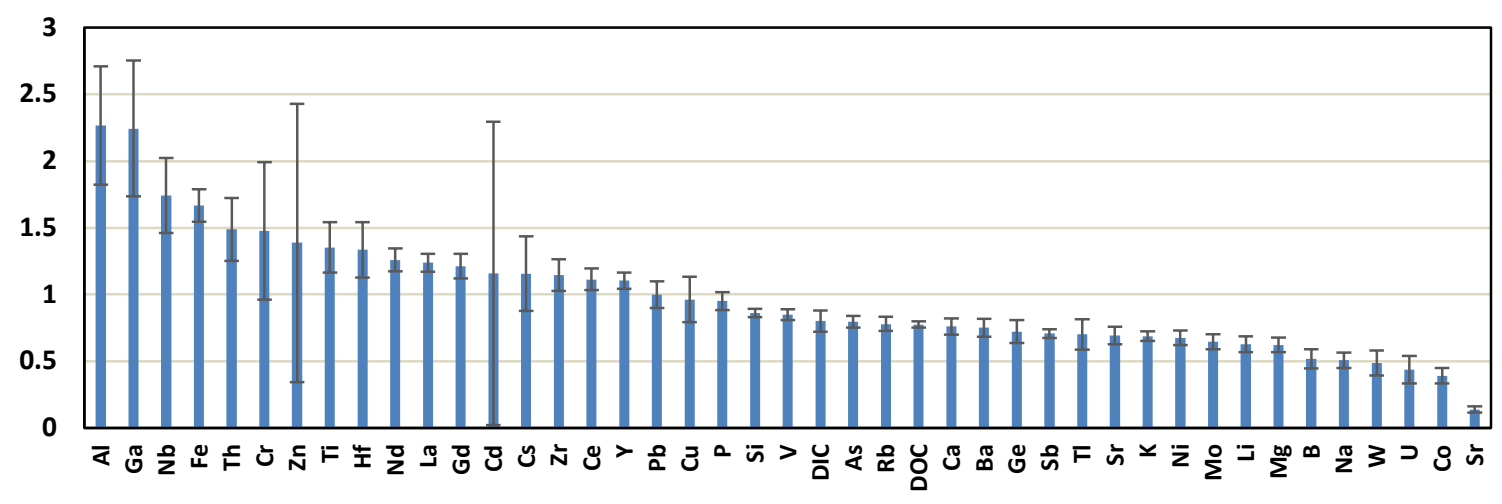

Figure 4. The ratio of average ( \pm s.d.) element concentration of element in the Ob River main stem downstream the Irtysh (till the $\mathrm{Ob}$ mouth) to the concentration in the Irtysh River. Values above 1 indicate sizable enrichment of the main stem in a given element by small tributaries in the north.

\subsection{Colloidal status of major and trace elements in the $\mathrm{Ob}$ River and tributaries}

The dialysis procedure allowed a first-order assessment of the colloidal fraction (defined as the $\%$ of the element in the $1 \mathrm{kDa}-0.45 \mu \mathrm{m}$ fraction divided by its total dissolved concentration in the < $0.45 \mu \mathrm{m}$ fraction). The percentage of colloidal fraction ranged from $0-10 \%\left(\mathrm{Cl}, \mathrm{SO}_{4}, \mathrm{DIC}, \mathrm{Na}, \mathrm{K}, \mathrm{Li}, \mathrm{B}\right.$, $\mathrm{Si}, \mathrm{Mg}$, Ca Mo) to 80-90\% (trivalent and tetravalent hydrolysates) as listed in Table S4. In the northern part of the basin (downstream of Irtysh), the distribution of colloidal forms of elements among the tributaries and the main stem was quite homogeneous. This allowed identification three main groups of solutes with respect to their colloidal status (Fig. 5): (1) alkalis and alkaline-earth metals, major anions and $\mathrm{Si}$, trace oxyanions (Mo, Sb, Ge) presenting between 0 and $20 \%$ of colloidal forms; (2) DOC, divalent transition metals (No, Cu, Cd), V, Cr, Cs, Tl, W and U which were sizably impacted 
by colloids (20-70\%), and (3) P, Fe, Mn, Co and all trivalent and tetravalent hydrolysates (Al, Ga, Y, REEs, Ti, Zr, Hf, Th) which were present essentially (> 70-80\%) in the colloidal form.

The DOC exhibited remarkably homogeneous proportion of colloidal forms $(42 \pm 3 \%)$ in the main stem and most tributaries including Irtysh. However, two most southern tributaries sampled for colloids (Ket' and Tom') exhibited much lower proportion of colloidal DOC as well as of Fe, Co, Ni. Other colloid-affected elements (Al, Ti, P, V, Cr, As, Ga, Y, Zr) also demonstrated the lowest proportion of colloids in southern tributaries (Irtysh, Ket and Tom). Uranium exhibited quite particular colloidal pattern, with gradual decreasing of colloidal fraction from the north (70-90\%) to the middle course including Irtysh (20 to 50\%) and further decreasing in two most southern tributaries Ket' and Tom' (3\%).

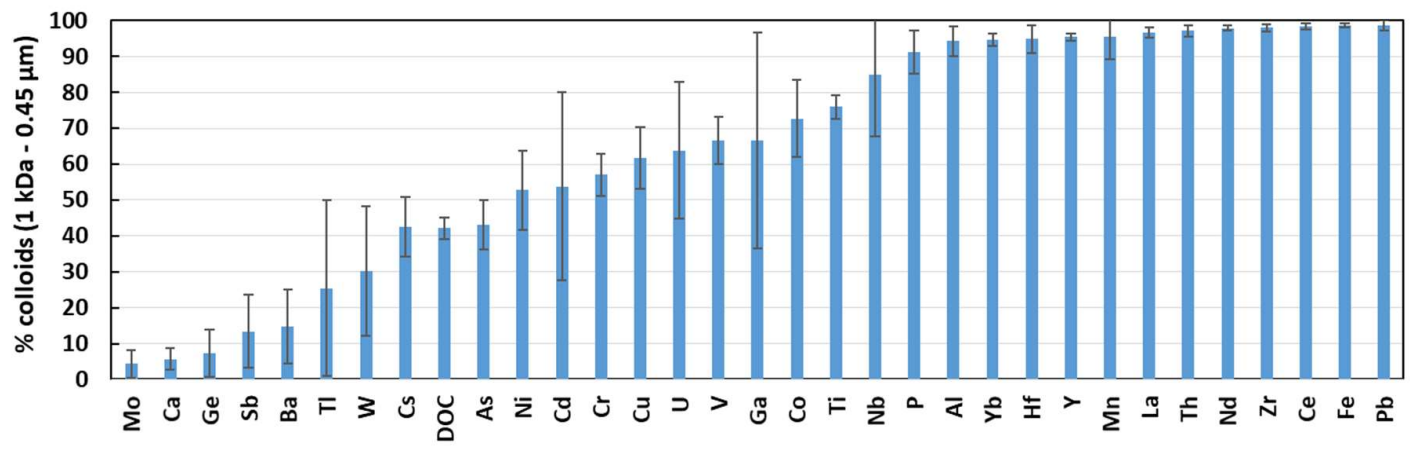

Figure 5. Proportion of colloidal fraction of elements in the Ob River downstream of Irtysh (4 points) and 3 tributaries (Pasaydeyakha, Poluy and Pitljar). Alkalis and alkaline-earth metals and oxyanions exhibit $<10 \%$ of colloids and not shown here.

Noteworthy that the role of the largest tributary (Irtysh) in colloidal pattern of the Ob River was not that significant: for most elements, their colloidal fraction in Irtysh was not statistically different from that of the main stem and downstream (northern) tributaries (Fig. S4).

\subsection{Testing the landscape, soil and Quaternary deposits control on element concentraion}

The main stem of the $\mathrm{Ob}$ River and its tributaries sampled in this study exhibited strong variability in main landscape parameters such as watershed size, MAAT, permafrost, forest, lake, bog and floodplain coverage as well as soils and Quaternary deposits. The main environmental parameters of the $\mathrm{Ob}$ River basin progressively evolved from the south to the north, which allowed testing the impact of climate and landscape on element concentration in several selected points of the main stem. The latitude of the sampling point, permafrost coverage and proportion of bogs, lakes, floodplain, lacustrine and fluvio-glacial Quaternary deposits of the watershed strongly correlated ( $\mathrm{p}$ $<0.05$ ) with DOC, Fe, $\mathrm{P}$, divalent metals ( $\mathrm{Mn}, \mathrm{Co}, \mathrm{Ni}, \mathrm{Cu}, \mathrm{Pb}), \mathrm{Rb}$ and low mobile lithogenic trace elements (Al, Ti, Cr, Y, Zr, Nb, REEs, Hf, Th) concentrations (Table S3 A, B; Fig. 6 and Fig. S5). The $\mathrm{pH}$ and concentrations of soluble, highly mobile elements (DIC, SO, Ca, Sr, Ba, Mo, Sb, W, U) positively correlated with the proportion of forest, loess and fertile soils, eluvial, eolian, and fluvial Quaternary deposits on the Ob River watershed (Fig. 6 and Fig. S5 where for a number of most important parameters such as forest coverage ( $\mathrm{pH}, \mathrm{Ca}, \mathrm{Mo}$ and $\mathrm{U}$ ), floodplain area (DOC, P, Fe, Th) and watershed coverage by fluvio-glacial deposits (DOC, Al, Fe, La) are illustrated). Other landscape factors were of secondary importance for element control yet exhibited sizable correlations with particular elements. Examples are podzol soil coverage of the watershed that was positively linked to concentration of $\mathrm{Al}, \mathrm{Cr}, \mathrm{Ga}$ and $\mathrm{Th}$, and saline soils that positively impacted the concentration of $\mathrm{Cl}, \mathrm{SO}_{4}, \mathrm{Li}, \mathrm{B}, \mathrm{Na}, \mathrm{K}, \mathrm{As}$ and $\mathrm{Rb}$ in the river water. 

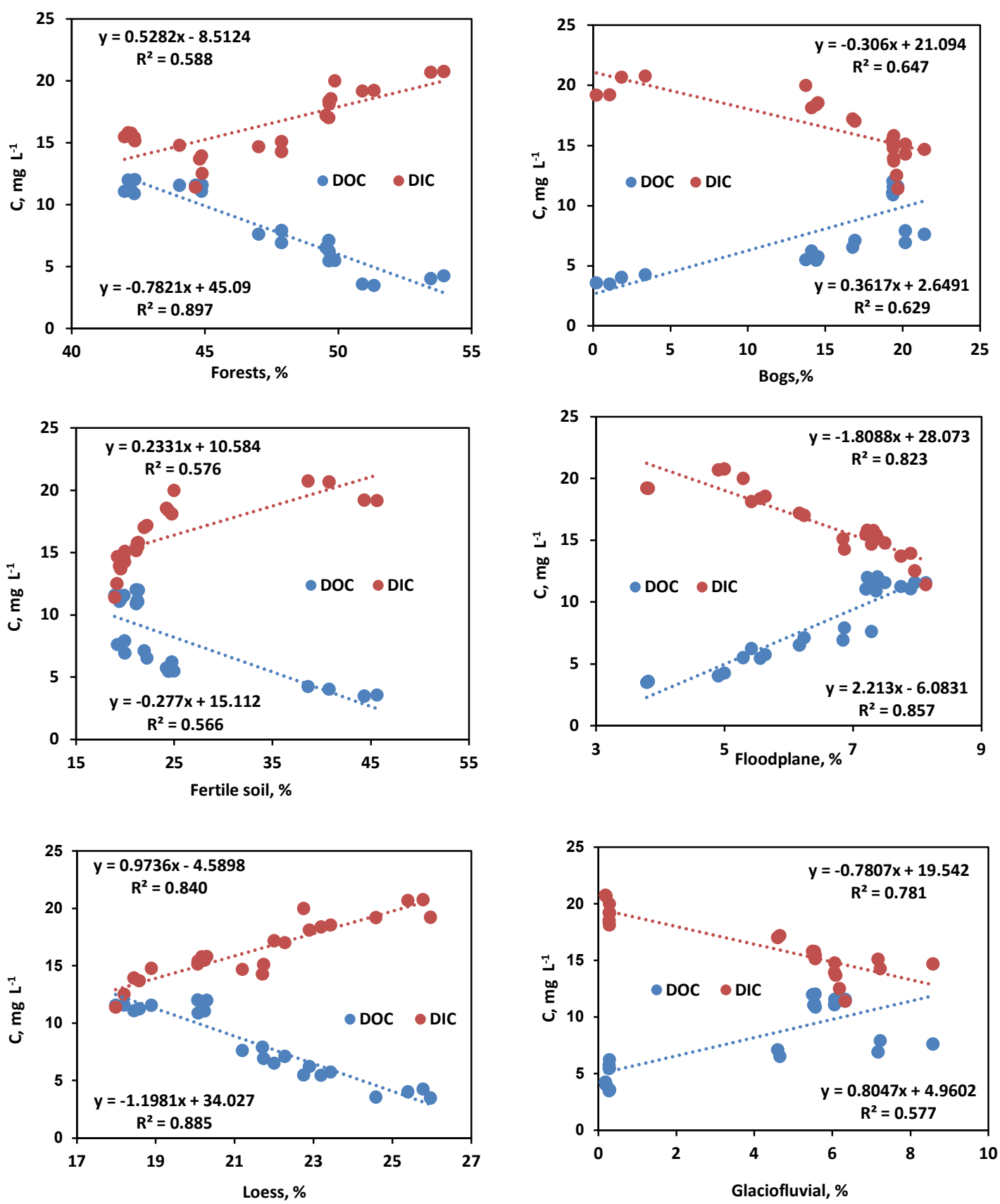

Figure 6. Examples of landscape factors, soil and Quaternary deposit control on DOC and DIC concentration in the $\mathrm{Ob}$ River. See examples of other factors and elements in Fig. S5. A correlation matrix of environmental parameters of the watershed and riverine solutes is provided in Table S3.

Pairwise correlations of riverine element concentration with landscape parameters of the watershed were further developed via multi-parametric statistical approach (Principal Component Analysis). Considering both the main stem of the Ob River and its tributaries, two main factors were revealed, accounting for $41 \%$ and $13 \%$ of total variability, respectively (Fig. 7). The F1 was presumably controlled by a northward increase in permafrost, floodplain, bogs, lakes and lacustrine deposits on the watersheds and acted on the DOC, Al, P, Ti, Fe, divalent metals, $\mathrm{Rb}, \mathrm{Cs}, \mathrm{Nb}$, and trivalent and tetravalent trace elements concentrations. The second factor (F2) included the Specific Conductivity, $\mathrm{SO}_{4}{ }^{2-}, \mathrm{Li}, \mathrm{B}, \mathrm{Na}$, labile alkaline-earth metals .Mg, 
$\mathrm{Sr}, \mathrm{Ba})$, oxyanions (Mo, Sb, W) and oxyanions (As, Sb) which were impacted by southwarddominating forest coverage, loesses, eluvial and fertile soils. This factorial structure was found to be highly stable and preserved in general features for both the $\mathrm{Ob}$ River main stem and tributaries, if treated separately (Fig. S6).

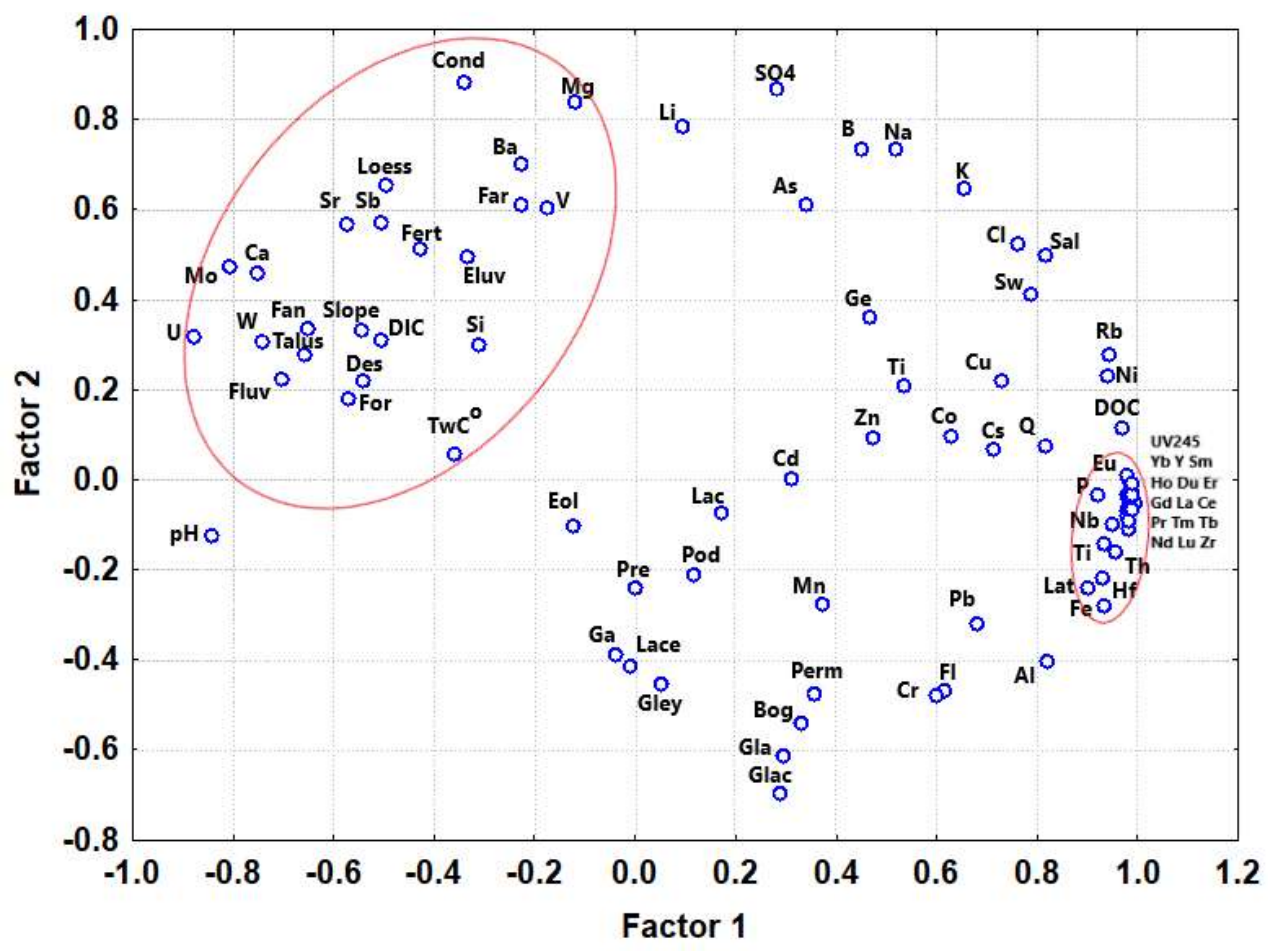

Figure 7. Results of the PCA treatment of all dataset (the Ob River main stem and tributaries) including elementary composition of the river water and landscape parameters of the watersheds. The landscape parameters (\% of watershed coverage) are abbreviated as following: For, Forest; Fl, floodplain; Perm, permafrost; Far, farmland; Pre, pre-Quaternary deposits; Glac, glacial deposits; Slope, slopewash deposits, Des, deserptium (rock stream deposits); Lac, lacustrine and glacio-lacustrine deposits; Fan, fan-alluvial deposits; Gla, glacial deposits; Eol, eolian deposits; Pod, podsols; Sal, saline soils; Fert, fertile soils; $\mathrm{TwC}^{\circ}$, Water temperature; Cond, Specific Conductivity.

\section{Discussion}

\subsection{Contrasting spatial pattern of DOC, major and trace elements between northern and southern river} segment is due to latitudinal patetrn of landscape, soil and Quaternary deposits.

The hydrochemical composition of the $\mathrm{Ob}$ River basin demonstrated several distinct groups of elements defined according to the latitudinal patterns of their concentrations, similar to what was reported for small rivers of the WSL $[31,36]$. The DOC, organically-bound metals (V, Cr, Mn, Fe, Co, $\mathrm{Ni}, \mathrm{Cu}, \mathrm{Zn}, \mathrm{Cd}$ and $\mathrm{Pb}$ ) and the majority of low soluble TE (Al, REEs, Nb, Ti, Zr, Hf, and Th) exhibited a minimal concentration in the upper reaches of $\mathrm{Ob}$ and a maximal concentration in the northern, permafrost-affected zone. The northward increase in concentration of these elements in both main stem and tributaries may originate from multiple factors. First, enhanced input of lithogenic low mobility elements in the northern part of the Ob River (permafrost zone) may occur due to a decrease of river connectivity with deep and shallow groundwater and an increase in the surface flow. The surface drainage through forest litter together with surface runoff from surrounding bogs led to river 
water enrichment in organic and organo-ferric, organo-aluminum (DOC, Fe, $\mathrm{Al}$ ) colloids [30,34]. These colloids act as main carriers of divalent metals, insoluble trivalent and tetravalent trace elements, $\mathrm{Pb}, \mathrm{Cr}, \mathrm{V}$ in western Siberian rivers [27, 28].

Another possible explanation for a northward increase in concentration of lithogenic and low mobile elements and a decrease in concentration of soluble labile elements lays in dynamics of peat formation / decay across the territory as recently suggested for small rivers of the WSL [36]. Because of on-going recovery from last glaciation, the WSL terrestrial ecosystems are not at the stationary stage: the growth of mires in the south leads to active accumulation of peat [40,41] whereas the permafrost peatlans in the north thaw and degrade [42-44]. Given that the WSL peat preferentially accumulates heavy metals $(\mathrm{V}, \mathrm{Cr}, \mathrm{Zn}, \mathrm{Pb})$, trivalent $\left(\mathrm{TE}^{3+}\right)$ and tetravalent $\left(\mathrm{TE}^{4+}\right)$ trace elements $(\mathrm{Al}, \mathrm{Y}$, REEs, Ti, Zr, Hf, Th) and is depleted in alkalis and alkaline-earths metals, As, and Mo [45], it is possible that riverine concentration of trace elements inherits the element cycling between the growing/decaying peat and surface hydrological network.

At the same time, the obtained results did not confirm completely the initial hypothesis. An expected northward decrease of concentration of ground-water originated soluble, highly mobile anions, alkalis and alkaline earth metals was not observed for $\mathrm{Cl}_{1} \mathrm{SO}_{4}, \mathrm{Na}$ and $\mathrm{K}$. Presumably, these elements bear the influence of salt soils of the Irtysh River which flows through partially salty steppe and forest-steppe landscapes. Further to the north, the Ob River drains through paleo-marine deposits containing salt minerals (based on sedimentary cores available from extensive drilling of the territory [46]). This may enrich the main stem in highly mobile $\mathrm{Na}, \mathrm{Cl}$ and $\mathrm{SO}_{4}$.

It is important to note that, unlike it was reported for water $\mathrm{pCO}_{2}$ and molecular composition of riverine DOM (i.e., 17, 18, 19], the Irtysh River does not play a regulatory role of the lower Ob River water chemistry in terms of concentrations of other major and trace elements including organomineral colloids. Instead, the hydrochemical conditions of the Ob River are shaped by integration of multiple tributaries those chemical composition gradually changes along the permafrost and landscape gradient, as it is known for other river basins of western Siberia such as Taz and Pur [36].

The concentration of riverine solutes was found to be strongly controlled by the abundance of bogs and lakes on the watershed and its floodplain coverage, for both the main stem and tributaries. The group of elements, positively correlated with wetlands, reflects a leading role of both organicrich soils and sediments of wetlands (unified here as bogs, lakes and floodplains) in DOC, P, K, divalent metals and insoluble elements mobilization (notably trivalent and tetravalent hydrolysates) from the watershed to the river. This presents a prominent contrast to very small boreal catchments described in Northern Sweden, where wetlands decreased the fluxes of metals from boreal forests to downstream $[47,48,49]$. According to these authors, such a decrease occurred due to a combination of low weathering in peat soils and accumulation of organophilic metals in peat. The contrast between northern Scandinavian and western Siberian settings is consistent with a possibility of peat degradation rather than accumulation in northern part of the Ob River basin (downstream of the confluence with Irtysh). This would lead to enhanced release of trace metals to the streams and rivers. It is also possible that the presence of permafrost in the northern part of the WSL greatly shortens the water and element pathways between wetlands and rivers, compared to that in the non-permafrost regions of northern Sweden. The transport of trace metals released from mineral soils under the forest towards the river is therefore strongly enhanced by allochthonous organic matter originated from peat bogs and generally wetlands of the region.

Another landscape parameter is the presence of podzol soils at the watershed. Similar to glacial quaternary deposits, these soils led to enrichment of the river water in low mobile, lithogenic elements such as Al, Cr, Ga, REE, Hf, Th (see Table S3). These elements mark the presence of primary silicate minerals, often developed on felsic moraine as it is shown in European boreal regions (i.e., ref. [50]).

In contrast to metals and low mobile trace elements, the DIC, alkaline-earth metals, oxyanions (Mo, As, W) and U, those concentration decreased northward, were positively affected by the presence of forest, loess, eluvial, fluvial and fertile soils. From the one hand, this can reflect a northward decrease of the connectivity between groundwaters (enriched in these elements; see ref. 
[51]) and surface waters due to increase in the permafrost coverage (i.e., ref. [33, 34]). From the other hand, a southward increase in watershed coverage by soils which are rich in these labile elements (loess and eluvial and eolian soils, containing carbonate concretions and fauna) may explain preferential enrichment in these elements in the southern part of the Ob River watershed. Note that eolian solid aerosol deposits in western Siberia are also enriched in these soluble elements [52]. It is not excluded that both factors (soils and groundwaters) are pronounced at the scale of such a large watershed.

Finally, the presence of saline soils in the southern part of the $\mathrm{Ob}$ basin produced sizable enrichment of the river water in anions $\left(\mathrm{Cl}, \mathrm{SO}_{4}\right), \mathrm{B}$, alkalis $(\mathrm{Li}, \mathrm{Na}, \mathrm{K})$ presumably originated from local surface salt deposits and evaporates.

\subsection{Riverine transport of trace element occurs in the form of organo-ferric colloids}

All major and trace elements in the Ob River and its tributaries presented a colloidal pattern which was similar to the one established for boreal and permafrost-affected zones of high latitudes $[28,37,53,54,55,56,57]$. Soluble, highly labile alkalis, anions and oxyanions were negligibly affected by colloids as they do not interact with organic matter or colloidal Fe/Al hydroxides and thus present in the form of simple ions or neutral molecules. The second group of colloidally-bound trace elements reflected their capacity to either complex with colloidal organic matter (divalent transition metals), or co-precipitate with organo-ferric colloids (trivalent and tetravalent hydrolysates).

A prominent feature of the major part of the Ob Basin is that spatial variability of colloid distribution among the tributaries and the main stem was rather low, and only two southern tributaries (Ket, Tym) presented remarkable contrast to the rest of the Ob River basin. This presumably reflects homogeneous physico-geographical and landscape parameters of the majority of $\mathrm{Ob}$ River and its tributaries north of Irtysh. The two southern tributaries exhibit less amount of bogs and lakes in their watersheds and contain carbonate minerals in their base rocks (clays and silts with carbonate concretions, ref. 30). In accord with previous studies of small rivers of the WSL [58], we hypothesize that the presence of carbonate rocks and decreasing the proportion of wetlands in the southern part of the $\mathrm{Ob}$ basin lead to 1) a decrease in concentration of DOC and Fe which can serve as main carriers of trace metals; 2 ) an increase in DIC concentration and enhanced delivery of ionic form of elements from the groundwater. The latter is facilitated by much stronger connectivity between DOC-poor, DIC-rich groundwater and surface waters in permafrost-free part of the $\mathrm{Ob}$ Basin [34].

An interesting and unexpected result is extremely high proportion of colloidal Mn (83 to $100 \%$ in all samples except Ket (23\%)). Typical colloidal fraction of $\mathrm{Mn}$ in boreal and permafrost-affected surface waters (rivers, lakes, bog waters) including peat porewater is between 80 and $20 \%$ [28, 29], and the summer period usually accounts for the lowest proportion of colloidal Mn, due to the dominance of low molecular weight $(<1 \mathrm{k} \mathrm{Da})$ exometabolites that are capable to complex divalent metals [27]. However, the lowest proportion of Mn colloids is observed only in the most southern tributary which also exhibits a low proportion of colloidal OC. In these sites, Mn is likely to be present as a divalent cation originated from the groundwater or complexed with autochthonous low molecular weight DOM. In contrast, the majority of $\mathrm{Mn}$ in all other tributaries and the main stem was tightly bound to colloids. We therefore hypothesize the transport of $\mathrm{Mn}$ in the form of high molecular weight, Fe-rich organic colloids in the main part of the Ob Basin. It is possible that high proportion of bogs on the watersheds of all rivers north of the Vasyugan River provides such an enhanced colloidal transport. These Mn-rich colloids are likely to be generated at the interface of anoxic and oxic surface waters of the bogs and then delivered to the river via surface flow. Note that enhanced riverine $\mathrm{Mn}$ transport in mire-affected regions is reported in Northern Europe [55, 59].

Another striking example of speciation control on element migration in the river water presents uranyl $\left(\mathrm{UO}_{2+}^{2+}\right)$ ion. Uranium (VI) speciation in surface waters rich in DOM and Fe is largely controlled by high molecular weight organo-ferric colloids $[28,60]$. In non-permafrost zone, these colloids are formed at the riparian/hyporheic zone of the river where the $\mathrm{Fe}(\mathrm{II})$ and $\mathrm{U}(\mathrm{VI})$-rich groundwaters mix 
with oxygenated, organic-rich surface waters [37]. In the permafrost zone, these colloids originate from surface flow over forest floor and mire waters. Thus, in the northern part of the Ob River basin, elevated concentrations of both Fe and DOC provide suitable conditions for $U$ transport in the form of colloids (70-90\% in the $1 \mathrm{kDa}-0.45 \mu \mathrm{m}$ form). Mires, which are highly abundant in the Ob basin north of Ket tributary, are also capable mobilizing uranium to the river water as it is known from other boreal setting [61]. In contrast, in southern part of the basin, the groundwater contacting with carbonate rocks of the basement or the loess soils are enriched in $\mathrm{HCO}_{3}{ }^{-}$which renders uranyl into soluble, non-colloidal carbonate complexes. Such a mechanism is fairly well known for other boreal regions which are impacted by carbonate rocks [62]. As a result, the proportion of colloidal form of $\mathrm{UO}_{2}(\mathrm{VI})$ progressively decreases southward and becomes as low as $3 \%$ in two most southern tributaries (Ket and Tom) which exhibit the highest DIC, Ca and the lowest DOC and Fe concentration. Overall, progressive southward decrease of colloidal status of $U$ reflects the increase of connectivity between surface and groundwaters of the WSL (i.e., ref. 34, 63) and a decrease of bog coverage of river watershed in the same direction.

\subsection{Possible impact of landscape changes on element concentration in the Ob River and its tributaries.}

Unique geographical position of the Ob River, which traverses, from the south to the north, several distinct landscape zones and encompasses a large permafrost, MAAT and vegetation gradient, allows to use a substituting space for time approach (i.e., ref. [64]) for foreseeing possible future changes in river water hydrochemistry based on contemporary pattern of riverine solutes. This approach has been efficiently used for small rivers of the WSL [30, 31, 33, 34, 35, 58], but, to the best of our knowledge, never attempted for the $\mathrm{Ob}$ River main stem. The restrictions of this approach are the following: lack of accounting for the time scale, necessary for the northern ecosystem to reach the new "more southern" state; ignoring possible shift in the structure of vegetation and soil microbial community, and change in hydrologic seasons. Considering these restrictions, only preliminary, firstorder assessment of possible changes can be made.

Given rather high similarity of riverine solutes in the $\mathrm{Ob}$ River and tributaries across different permafrost zones, north of Irtysh (excluding the most southern part, south of Vasyugan), the shift in permafrost boundaries or the increase in the thickness of the active layer $[65,66,67,68]$, are not expected to sizably impact the hydrochemical composition of rivers in the Ob basin, unless the connectivity between deep underground and surface waters is modified (i.e., 10, 30). The latter may lead to enhanced concentration of soluble highly mobile elements in the north, as it is demonstrated for the case of small WSL rivers of the Pur and Taz watersheds [27].

At the same time, the elements affected by possible adsorption on clay minerals underlying the peat deposits, first of all, DOC (see $[69,70,71,72,73]$ may modify their concentration in the northern part of the $\mathrm{Ob}$ basin. Given that wetlands (bogs, lakes and floodplain zone) were the main controlling factor of element concentration in the main stem and tributaries across the studied spatial gradient, we believe that global-level changes in WSL landscape such as forestation of the northern part and decrease in the proportion of bogs, all induced by changes in atmospheric precipitation, terrestrial productivity and duration of open-water seasons [i.e., 74]. However, quantification of the impact of these factors requires extensive ecosystem-level regional modeling which goes beyond the scope of this study.

\section{Conclusions}

Based on the $3000 \mathrm{~km}$ sampling transect of the Ob River and its 11 tributaries performed during end of the spring flood - beginning of the summer baseflow period, this snapshot study of large Arctic river dissolved $(<0.45 \mu \mathrm{m})$ load revealed the dominant physio-geographical control on the hydrochemistry of the river water.

The latitudinal pattern of element concentration in the main stem was strongly pronounced and distinguished two main groups of solutes. The spatial variations of main stem hydrochemistry were generally consistent with previous studies on carbon in the Ob River and on major and trace elements 
in small rivers of the WSL. The first group included mobile elements bearing the influence of groundwaters, connected to the river waters in the southern part of the WSL. These are DIC, Ca, Mo, $\mathrm{W}$, and $\mathrm{U}$ which sizably (by a factor of 2.0) decreased their concentrations northward. The $2^{\text {nd }}$ group of elements included $\mathrm{DOC}, \mathrm{P}, \mathrm{Mn}, \mathrm{Al}, \mathrm{Fe}, \mathrm{Ti}, \mathrm{Ni}, \mathrm{Cu}, \mathrm{Co}, \mathrm{Rb}, \mathrm{Pb}, \mathrm{Y}, \mathrm{Zr}, \mathrm{Nb}, \mathrm{REE}, \mathrm{Hf}$ and Th which strongly (by a factor of 2 to 10) increased their concentration in the Ob River main stem from the south to the north. For these elements, the increase in concentrations occurred after confluence with Vasyugan River draining through the world's largest mire of peatland-lake complex.

The land cover approach allowed testing the control of main physio-geographical parameters of the $\mathrm{Ob}$ River watersheds on element concentration along the main steam and among the tributaries. Bogs, floodplain and lake coverage and permafrost presence on the watershed were found to be the main factors of northward increasing in concentration of DOC and low-soluble trace element, which were present in the form of organic and organo-mineral colloids $(\mathrm{Fe}, \mathrm{Mn}, \mathrm{Al}, \mathrm{V}, \mathrm{Cr}, \mathrm{Co}, \mathrm{Ni}, \mathrm{Cu}, \mathrm{Zn}$, $\mathrm{Cd}$ and $\mathrm{Pb}$ and lithogenic trivalent and tetravalent $\mathrm{TE}(\mathrm{Al}, \mathrm{Ti}, \mathrm{Zr}, \mathrm{Hf}, \mathrm{Th})$ and REEs. These elements were also positively affected by the presence of glacial, lacustrine and fluvio-glacial Quaternary deposits. In contrast, soluble highly mobile alkalis, alkaline-earth metals, $\mathrm{DIC}, \mathrm{SO}_{4}, \mathrm{~B}, \mathrm{Mo}, \mathrm{Sb}, \mathrm{As}, \mathrm{W}$ and $\mathrm{U}$ were positively affected by the presence of forest developed on loesses, fertile and saline soils, eluvial, fluvial and eolian Quaternary deposits given that these substrates could contain soluble carbonate minerals and salt inclusions.

We revealed high homogeneity in both element concentration and colloidal status in the main stem of the $\mathrm{Ob}$ River and its tributaries located north of the confluence with Irtysh. Presumably, the distribution of wetlands (bogs, floodplains, lakes and lacustrine deposits) was the dominant factor defining elementary pattern in waters of the $\mathrm{Ob}$ basin whereas the permafrost exhibited a subordinary control. As such, in case of drastic environmental changes in the WSL territory (permafrost boundary shift and active layer depth increase, vegetation coverage, precipitation regime), the changes of bogs, lakes and forest distribution rather than permafrost thaw might become the governing factors of modifications in the river hydrochemical regime.

Supplementary Materials: The following are available online at www.mdpi.com/xxx/s1, Figure S1: Latitudinal dependence of $\mathrm{Cl}, \mathrm{SO}_{4}, \mathrm{Na}, \mathrm{K}$ and $\mathrm{Pb}$ concentration in the main stem of the Ob River; Figure S2: Main stem concentration of elements which do not show any particular pattern with latitude: $\mathrm{Si}, \mathrm{Mg}, \mathrm{Cu}, \mathrm{V}, \mathrm{As}$ and $\mathrm{Sb}$; Figure S3: A histogram of elemental ratio in 2 northern tributaries (downstream of Irtysh) to 8 southern tributaries (upstream of Irtysh) of the Ob River; Figure S4: Proportion of colloidal ( $1 \mathrm{kDa}-0.45 \mu \mathrm{m})$ fraction of DOC, $\mathrm{Ca}, \mathrm{Fe}, \mathrm{Mn}, \mathrm{Al}, \mathrm{Cu}, \mathrm{U}$, La and Th in the main stem (blue box plot column) and tributaries of the southern (blue circles) and northern (red circles) part of the Ob Basin; Fig. S5. Examples of major and trace element concentration with landscape parameters of the Ob River main stem and tributaries; Fig. S6. Results of PCA treatment of the solute data and watershed characteristics (separately Ob main stem and tributaries). Table S1: List of sampled sites at the main stem of the $\mathrm{Ob}$ River and its tributaries. Table S2: Main landscape parameters and genetic type of Quaternary deposits (\% of the watershed coverage) of the tributaries and several key points at the $\mathrm{Ob}$ River main stem; Table S3: A correlation matrix of element concentration in the $\mathrm{Ob}$ main stem tributaries and landscape coverage (\%) of the watersheds; Table S4: Proportion of colloidal fraction of elements in the $\mathrm{Ob}$ River downstream of Irtysh (4 points) and 7 tributaries.

Author Contributions: YK and OP designed the study and wrote the paper; YK, LK, SV performed sampling, analysis of major cations and their interpretation; IP was the leader of the ship expedition and provided data interpretation; LS was in charge of DOC, DIC and anion measurements and their interpretation; LK and YK provided GIS-based interpretation, mapping and identification of river watersheds. Each co-author have seen and approved the final paper and contributed to writing the manuscript.

Acknowledgments: We acknowledge main support from the Russian Scientific Foundation, RSF grant No 1817-00237_P and grant No 21-77-30001 to IS, as well as by the Russian Foundation for Basic Research, RFBR grants No 19-55-15002, 20-05-00729_a, and RSF grant No 18-77-10045 for field work and a Belmont Forum VULCARFATE grant for some laboratory analyses. The study was partly carried out using the research equipment of the Unique Research Installation "System of experimental bases located along the latitudinal gradient" TSU with financial support from the Ministry of Education and Science of Russia (RF -- 2296.61321X0043, agreement No. 075- 15-2021-672). Furthermore, this study was supported by the Ministry of Education and Science of Russia (grant No 121-021-500057-4). 
Conflicts of Interest: The authors declare no conflict of interest.

\section{References}

1. Turetsky, M.R.; Abbott, B.W.; Jones, M.C.; Anthony, K.W.; Olefeldt, D.; Schuur, E.A.G.; Grosse, G.; Kuhry, P.; Hugelius, G.; Koven, C.; Lawrence, D.M.; Gibson, C.; Sannel, A. B. K.; McGuireet, A.D. Carbon release through abrupt permafrost thaw. Nat. Geosci. 2020, 13, 138-143, doi:10.1038/s41561-019-0526-0

2. Vonk, J.E., Tank, S.E., Walvoord, M.A. Integrating hydrology and biogeochemistry across frozen landscapes. Nat. Commun. 2019, 10, 1-4. https://doi.org/10.1038/s41467-019-13361-5

3. Gordeev, V.V.; Martin, J.-M.; Sidorov, I.S.; Sidorova, M.V. A reassessment of the Eurasian river input of water, sediment, major elements, and nutrients to the Arctic Ocean. Am. J. Sci. 1996, 296, 664-691.

4. Cooper, L.W.; McClelland, J.W.; Holmes, R.M.; Raymond, P.A.; Gibson, J.J.; Guay, C.K.; Peterson, B. J. Flowweighted values of runoff tracers $\left(\delta^{18} \mathrm{O}, \mathrm{DOC}, \mathrm{Ba}\right.$, alkalinity) from the six largest Arctic rivers. Geophys. Res. Lett. 2008, 35, L18606, doi:10.1029/2008GL035007.

5. McClelland, J.W.; Déry, S.J.; Peterson, B.J.; Holmes, R.M.; Wood, E.F. A pan-arctic evaluation of changes in river discharge during the latter half of the 20th century. Geophys. Res. Lett. 2006, 33, doi:10.1029/2006GL025753.

6. Holmes, R.M.; Coe, M.T.; Fiske, G.J.; Gurtovaya, T.; McClelland, J.W.; Shiklomanov, A.I.; Spencer, R.G.M.; Tank, S.E.; Zhulidov, A.V. Climate change impacts on the hydrology and biogeochemistry of Arctic Rivers, In: Climatic Changes and Global warming of Inland Waters: Impacts and Mitigation for Ecosystems and Societies, Eds. C.R. Goldman, M. Kumagi, and R.D. Robarts, John Wiley and Sons, p. 1-26, 2013.

7. McClelland, J.W.; Holmes, R.M.; Peterson, B.J.; Raymond, P.A.; Striegl, R.G.; Zhulidov, A.V.; Zimov, S.A.; Zimov, N.; Tank, S.E.; Spencer, R.G.M.; et al. Particulate organic carbon and nitrogen export from major Arctic rivers. Global Biogeochem. Cy. 2016, 30, 629-643, doi:10.1002/2015GB005351.

8. Lammers, R.B.; Shiklomanov, A.I. A regional Hydrometeorological Data Network for Russia. 2013. Available online: https://www.r-arcticnet.sr.unh.edu/v4.0/main.html.

9. Ahmed, R.; Prowse, T.; Dibike, Y.; Bonsal, B.; O’Neil, H. 2020. Recent trends in freshwater influx to the Arctic Ocean from four major Arctic-draining rivers. Water 12, 1189, doi: 10.3390/w12041189.

10. Frey, K.E. and McClelland, J.W. Impacts of permafrost degradation on arctic river biogeochemistry, Hydrol. Process. 2009, 23, 169-182. 1, doi:10.1002/hyp.7196.

11. Vorobyev, S.N.; Pokrovsky, O.S.; Kolesnichenko, L.G.; Manasypov, R.M.; Shirokova, L.S.; Karlsson, J.; Kirpotin, S.N. Biogeochemistry of dissolved carbon, major, and trace elements during spring flood periods on the Ob River. Hydrological Processes 2019, 33, 1579-1594, doi:10.1002/hyp.13424.

12. Beilman, D.W.; MacDonald, G.M.; Smith, L.C.; Reimer, P.J. Carbon accumulation in peatlands of West Siberia over the last 2000 years. Global Biogeochem. Cy. 2009, 23, doi:10.1029/2007GB003112.

13. Wang, P.; Huang, Q.; Pozdniakov, S.P.; Liu, S.; Ma, N.; Wang, T. et al. Potential role of permafrost thaw on increasing Siberian river discharge. Environ. Res. Lett. 2021, 16, 034046.

14. Xu, M.; Kang, S.; Wang, X.; Wu, H.; Hu, D.; Yang, D.Q. Climate and hydrological changes in the Ob River Basin during 1936-2017. Hydrol. Processes 2020, 34(8), 1821-1836. https://doi.org/10.1002/hyp.13695.

15. Kaiser, K.; Canedo-Oropeza, M.; McMahon, R.; Amon, R.M.W. Origins and transformations of dissolved organic matter in large Arctic rivers. Sci. Rep. 2017, 7, 13064. Doi:10.1038/s41598-017-12729-1.

16. Huang, J.; Wu, M.; Cui, T. ; Yang, F. Quantifying DOC and its controlling factors in major Arctic rivers during ice-free conditions using Sentinel-2 data. Remote Sensing 2019, 11, 2904; doi:10.3390/rs11242904.

17. Pipko, I.I.; Pugach, S.P.; Savichev, O.G. et al. Dynamics of dissolved inorganic carbon and $\mathrm{CO}_{2}$ fluxes between the water and the atmosphere in the main channel of the Ob River. Dokl. Chem. 2019, 484, 52-57, https://doi.org/10.1134/S0012500819020101.

18. Karlsson, J.; Serikova, S.; Vorobyev, S.N.; Rocher-Ros, G.; Denfeld, B.; Pokrovsky, O.S. Carbon emission from Western Siberian inland waters. Nature Communication 2021, 12, 825, https://doi.org/10.1038/s41467-02121054-1.

19. Perminova, I.V.; Shirshin, E.A.; Zherebker, A.; Pipko, I.I.; Pugach, S.P.; Dudarev, O.V. et al. Signatures of molecular unification and progressive oxidation unfold in dissolved organic matter of the Ob-Irtysh River system along its path to the Arctic Ocean. Sci. Rep. 2019, 9, 19487. 
20. Savichev, O.G., Mazurov, A.K., Pipko, I.I.; Sergienko, V.I.; Semiletov, I.P. Spatial patterns of the evolution of the chemical composition and discharge of river water in the Ob River basin. Dokl. Earth Sciences 2016, 466, 59-63. https://doi.org/10.1134/S1028334X16010141.

21. Mu, C. ; Zhang, F. ; Chen, X.; Ge, S.; Mu, M.; Jia, L.; Wu, Q.; Zhang, T. Carbon and mercury export from the Arctic rivers and response to permafrost degradation. Water Res. 2019, 161, 54-60.

22. Sonke, J.E.; Teisserenc, R.; Heimbürger-Boavida, L.E.; Petrova, M. V., Marusczak, N.; Le Dantec, T.; Chupakov, A.V.; Li, C.; Thackray, C.P.; Sunderland, E.M.; Tananaev, N.; Pokrovsky, O.S. Eurasian river spring flood observations support net Arctic Ocean mercury export to the atmosphere and Atlantic Ocean. P. Natl. Acad. Sci. USA 2018, 115(50), E11586-E11594. https://doi.org/10.1073/pnas.1811957115.

23. Semenkov, I.N.; Miroshnikov, A.Yu.; Asadulin, En.En.; Usacheva, A.A.; Velichkin, V.I.; Laverov, N.P. The $\mathrm{Ob}$ River Basin as source of Kara Sea Contamination with global fallout of cesium-137. Dokl. Earth Sciences 2015, 463(1), 704-706. https://doi.org/10.1134/S1028334X1507003X

24. Kharanzhevskaya, Y.; Maloletko, A.; Sonyutkina, A.; Gielczewski, M.; Kirschey, T. et al. Assesing mire-river interaction in a pristine Siberian bog-dominated watershed - Case study of a part of the Great Vasyugan Mire, Russia. J. Hydrol. 2020, 590, 125315.

25. Kharanzhevskaya, Y.; Voistinova, E.S. ; Sinyutkina, A.A. Spatial and temporal variations in mire surface water chemistry as a function of geology, atmospheric circulation and zonal features in the south-eastern part of Western Siberia. Sci. Total Environ. 2020, 733, 139343.

26. Moskovchenko D. V., Babushkin A. G., Pikinerov P. V. 2017. “Ecological and Hydrochemical Characteristics of Wetlands “Upper Dvuobye'”. Tyumen State University Herald. Natural Resource Use and Ecology, vol. 3, no 2, pp. 8-21. DOI: 10.21684/2411-7927-2017-3-2-8-21

27. Krickov, I.V.; Pokrovsky, O.S.; Manasypov, R.M.; Lim, A.G.; Shirokova, L.S.; Viers, J. Colloidal transport of carbon and metals by western Siberian rivers during different seasons across a permafrost gradient. Geochim. Cosmochim. Acta 2019, 265, 221-241, doi:10.1016/j.gca.2019.08.041.

28. Pokrovsky, O.S.; Manasypov, R.M.; Loiko, S.V.; Shirokova, L.S. Organic and organo-mineral colloids in discontinuous permafrost zone. Geochim. Cosmochim. Acta 2016, 188, 1-20, doi:10.1016/j.gca.2016.05.035.

29. Raudina, T.V.; Loiko, S.; Kuzmina, D.M.; Shirokova, L.S.; Kulizhsky, S.P.; Golovatskaya, E.A.; Pokrovsky O.S. Colloidal organic carbon and trace elements in peat porewaters across a permafrost gradient in Western Siberia. Geoderma 2021, 390, Art No 114971, https://doi.org/10.1016/j.geoderma.2021.114971.

30. Pokrovsky, O.S.; Manasypov, R.M.; Shirokova, L.S.; Loiko, S.V.; Krickov, I.V.; Kopysov, S. Zemtzov V.A.; Kulizhsky S.P.; Vorobyev S.N.; Kirpotin S.N. Permafrost coverage, watershed area and season control of dissolved carbon and major elements in western Siberia rivers. Biogeosciences 2015, 12, 6301-6320.

31. Pokrovsky, O.S.; Manasypov, R.M.; Loiko, S.; Krickov, I.A.; Kopysov, S.G.; Kolesnichenko, L. G.; Vorobyev, S.N.; Kirpotin, S.N. Trace element transport in western Siberia rivers across a permafrost gradient. Biogeosciences 2016, 13(6), 1877-1900.

32. Vorobyev, S.N.; Kolesnichenko, Y.; Korets, M.A.; Pokrovsky, O.S. Testing landscape, climate and lithology impact on carbon, major and trace elements of the Lena River and its tributaries during a spring flood period. Water 2021, 13, 2093. https://doi.org/10.3390/w13152093

33. Frey, K.E.; McClelland, J.W.; Holmes, R.M.; Smith, L.C. Impacts of climate warming and permafrost thaw on the riverine transport of nitrogen and phosphorus to the Kara Sea. J. Geophys. Res. 2007, 112, doi:10.1029/2006JG000369.

34. Frey, K.E.; Siegel, D.I.; Smith, L.C. Geochemistry of west Siberian streams and their potential response to permafrost degradation. Water Resour. Res. 2007, 43, doi:10.1029/2006WR004902.

35. Frey, K.E.; Smith, L.C. Amplified carbon release from vast West Siberian peatlands by 2100. Geophys. Res. Lett. 2005, 32, doi: 10.1029/2004GL022025.

36. Pokrovsky, O.S.; Manasypov, R.M.; Kopysov, S.; Krickov, I.V.; Shirokova, L.S.; Loiko, S.V.; Lim, A.G.; Kolesnichenko, L.G.; Vorobyev, S.N.; Kirpotin, S.N. Impact of permafrost thaw and climate warming on riverine export fluxes of carbon, nutrients and metals in western Siberia. Water, 2020, 12, Art No 1817, doi:10.3390/w12061817.

37. Vasyukova, E.V.; Pokrovsky, O.S.; Viers, J.; Oliva, P.; Dupré, B.; Martin, F.; Candaudaup, F. Trace elements in organic- and iron-rich surficial fluids of the boreal zone: Assessing colloidal forms via dialysis and ultrafiltration. Geochim. Cosmochim. Acta 2010, 74, 449-468.

38. Prokushkin, A. S.; Pokrovsky, O. S.; Shirokova, L. S.; Korets, M. A.; Viers, J.; Prokushkin, S. G.; Amon, R.M.W.; Guggenberger, G.; McDowell, W. H. Sources and the flux pattern of dissolved carbon in rivers of the Yenisey 
basin draining the Central Siberian Plateau. Environ. Research Letters 2011, 6(4), 045212, doi: 10.1088/17489326/6/4/045212.

39. Pokrovsky O, O.S.; Kolesnichenko L.G. (2021) Chemical composition and landscape parameters of the Ob River and its tributaries, July 2016. Mendeley Database, https://data.mendeley.com//datasets/dkbypg976y/1.

40. Kirpotin S.N.; Joosten H.; Tanneberger F.; Elshehawi S.; Semenova N.M.; Volkova I.I.; Volkov I.V.; Feurdean A.; Pokrovsky O.S.; Antoshkina O.A.; Berezin A.E. Great Vasyugan Mire: How the world's largest peatland helps addressing the world's largest problems. Ambio 2021, https://doi.org/10.1007/s13280-021-01520-2.

41. Antipina, T.G.; Preis, Yu.I.; Zenin, V.N. Dynamics of forest vegetation and climate in the southern taiga of Western Siberia in the Late Holocene according to spore-pollen analysis and AMS dating of the peat bog. Russ. J. Ecol. 2019, 50, 445-452, doi:10.1134/S1067413619050035.

42. Fotiev, S.M. Arctic peatlands of the Yamal-Gydan province of Western Siberia. Earth's Cryosphere 2017, XXI, doi:10.21782/EC1560-7496-2017-5(3-13).

43. Loiko, S.; Raudina, T.; Lim, A.; Kuzmina, D.; Kulizhskiy, S.; Pokrovsky, O. Microtopography Controls of Carbon and Related Elements Distribution in the West Siberian Frozen Bogs. Geosciences 2019, 9, 291, doi: $10.3390 /$ geosciences 9070291.

44. Panova, N.K.; Trofimova, S.S.; Antipina, T.G.; Zinoviev, E.V.; Gilev, A.V.; Erokhin, N.G. Holocene dynamics of vegetation and ecological conditions in the southern Yamal Peninsula according to the results of comprehensive analysis of a relict peat bog deposit. Russ J Ecol 2010, 41, 20-27, doi:10.1134/S1067413610010042.

45. Stepanova, V. M.; Pokrovsky, O. S.; Viers, J.; Mironycheva-Tokareva, N. P.; Kosykh, N. P.; Vishnyakova, E. K. Major and trace elements in peat profiles in Western Siberia: impact of the landscape context, latitude and permafrost coverage. Appl. Geochem. 2015, 53, 53-70.

46. Liss, O. L.; Abramova, L. I.; Avetov, N. A.; Berezina, N. A.; Inisheva, L. I.; Kurnishnikova, T. V.; Sluka, Z. A.; Tolpysheva, T. Yu.; Shvedchikova, N. K. Wetland Systems of West Siberia and Their Importance for Nature Conservation; Grifi K publisher, Tula, Russia, 584 pp., 2001 (in Russian).

47. Lidman, F.; Morth, C. M.; Laudon, H. Landscape control of uranium and thorium in boreal streams spatiotemporal variability and the role of wetlands. Biogeosciences 2012, 4773-4785 ),11(9 .

48. Kohler, S.J.; Lidman, F; Laudon, H. Landscape types and $\mathrm{pH}$ control organic matter mediated mobilization of $\mathrm{Al}, \mathrm{Fe}, \mathrm{U}$ and La in boreal catchments. Geochim. Cosmochim. Acta 2014, 135,190-202 .

49. Lidman, F; Kohler, S J.; Morth, C-M., et al. (2014) Metal Transport in the Boreal Landscape-The Role of Wetlands and the Affinity for Organic Matter. Environ. Sci. Technol. 2014, 48(7), 3783-3790.

50. Vasyukova E.V.; Oliva P.; Viers J.; Martin F.; Dupre B.; Pokrovsky O.S. Chemical weathering of mafic rocks in boreal subarctic environment (North-West Russia) under influence of glacial moraine deposits. Chem. Geol. 2019, 509, 115-133.

51. Pasechnik E.Yu., Guseva N.V., Savichev O.G., Lgotin V.A., Balobanenko A.A., Domarenko V.A., Vladimirova O.N. Trace elements composition of underground waters of the upper hydrogeodynamic zone in the basin of upper $\mathrm{Ob}$ as a factor of formation of their ecological-geochemical condition. Bull. Tomsk Polytech. Univ. Geo Assets Eng., 2020, 331, 54-63.

52. Shevchenko, V.P.; Pokrovsky, O.S.; Vorobyev, S.N.; Krickov, I.V., et al. Impact of snow deposition on major and trace element concentrations and fluxes in surface waters of Western Siberian Lowland. Hydrology Earth System Sciences 2017, 21, 5725-5746, https://doi.org/10.5194/hess-21-5725-2017.

53. Pokrovsky, O.S.; and Schott, J. Iron colloids/organic matter associated transport of major and trace elements in small boreal rivers and their estuaries (NW Russia). Chemical Geology 2002, 190, 141-179.

54. Lyvén B.; Hassellöv M.; Turner D.R.; Haraldsson C.; Andersson K. Competition between iron- and carbonbased colloidal carriers for trace metals in a freshwater assessed using flow field-flow fractionation coupled to ICPMS. Geochim. Cosmochim. Acta 2003, 67, 3791-3802.

55. Ingri, J.; Widerlund, A.; Land, M. Geochemistry of major elements in a pristine boreal river system; Hydrological compartments and flow paths. Aquatic Geochem. 2005, 11, 57-88.

56. Ingri J.; Malinovsky D.; Rodushkin I.; Baxter D.C.; Widerlund A.; Andersson P.; Gustafsson Ö.; Forsling W.; Öhlander B. Iron isotope fractionation in river colloidal matter. Earth Planet. Sci. Lett. 2006, 245(3-4), 792-798.

57. Ilina, S.M.; Poitrasson F.; Lapitsky S.A.; Alekhin Yu.V.; Viers J.; Pokrovsky O.S. Extreme iron isotope fractionation between colloids and particles of boreal and temperate organic-rich waters. Geochim. Cosmochim. Acta, 2013, 101, 96-111. 
58. Krickov, I.V.; Lim, A.G.; Manasypov, R.M.; Loiko, S.V.; Vorobyev, S.N.; Shevchenko, V.P.; Dara, O.M.; Gordeev, V.V.; Pokrovsky, O.S. Major and trace elements in suspended matter of western Siberian rivers: First assessment across permafrost zones and landscape parameters of watersheds. Geochim. Cosmochim. Acta 2020, 269, 429-450, doi:10.1016/j.gca.2019.11.005

59. Björkvald, L.; Buffam, I.; Laudon, H.; Morth, C. Hydrogeochemistry of Fe and Mn in small boreal streams: the role of seasonality, landscape type and scale. Geochim. Cosmochim. Acta 2008, 72(12), 2789-2804.

60. Bagard, M.L.; Chabaux, F.; Pokrovsky, O.S.; Prokushkin, A.S.; Viers, J.; Dupré B.; Stille, P. Seasonal variability of element fluxes in two Central Siberian rivers draining high latitude permafrost dominated areas. Geochim. Cosmochim. Acta, 2011, 75, 3335-3357.

61. Porcelli, D.; Andersson, P.S.; Wasserburg, G.J.; Ingri, J.; Baskaran M. The importance of colloids and mires for the transport of uranium isotopes through the Kalix River watershed and Baltic Sea. Geochim. Cosmochim. Acta 1997, 61(19), 4095-4113.

62. Chupakov, A.V.; Pokrovsky, O.S.; Moreva, O.Y.; Shirokova, L.S.; Neverova, N.V.; Chupakova, A.A.; Kotova, E.I.; Vorobyeva, T.Y. High resolution multi-annual riverine fluxes of organic carbon, nutrient and trace element from the largest European Arctic river, Severnaya Dvina. Chemical Geology 2020, 538, doi:10.1016/j.chemgeo.2020.119491.

63. Ala-Aho, P.; Soulsby, C.; Pokrovsky, O.S.; Kirpotin, S.N.; Karlsson, J.; Serikova, S.; Vorobyev, S.N.; Manasypov, R.M.; Loiko, S.; Tetzlaff, D. Using stable isotopes to assess surface water source dynamics and hydrological connectivity in a high-latitude wetland and permafrost influenced landscape. J. Hydrol. 2018, 556, 279-293.

64. Blois, J.L.; Williams, J.W.; Fitzpatrick, M.C.; Jackson, S.T.; Ferrier, S. Space can substitute for time in predicting climate-change effects on biodiversity. PNAS 2013, 110, 9374-9379, doi:10.1073/pnas.1220228110.

65. Stendel, M.; Christensen, J.H. Impact of global warming on permafrost conditions in a coupled GCM. Geophys. Res. Lett. 2002, 29(13), 1632, doi:10.1029/2001GL014345.

66. Anisimov, O.; Kokorev, V.; Zhil'tsova, Y. Temporal and spatial patterns of modern climatic warming: case study of Northern Eurasia. Climatic Change 2013, 118, 871-883, doi:10.1007/s10584-013-0697-4.

67. Romanovsky, V.E.; Drozdov, D.S.; Oberman, N.G.; Malkova, G.V.; Kholodov, A.L.; Marchenko, S.S.; Moskalenko, N.G.; Sergeev, D.O.; Ukraintseva, N.G.; Abramov, A.A.; Gilichinsky, D.A., Vasiliev, A.A. Thermal state of permafrost in Russia. Permafrost Periglacial Proc. 2010, 21, 136-155, doi:10.1002/ppp.683.

68. Vasiliev, A. A.; Streletskaya, I. D.; Shirokov, R. S.; Oblogov,G. E. Evolution of cryolithozone of coastal zone of western Yamal during climate change. Kriosfera Zemli 2011, 2, 56-64.

69. Gentsch, N.; Mikutta, R.; Alves, R. J. E.; Barta, J.; Capek, P.; Gitte, A.; Hugelius, G.; Kuhry, P.; Lashchinskiy, N.; Palmtag, J.; Richter, A.; Santrucková, H.; Schnecker, J.; Shibistova, O.; Urich, T.; Wild, B.; Guggenberger, G. Storage and transformation of organic matter fractions in cryoturbated permafrost soils across the Siberian Arctic. Biogeosciences 2015, 12, 4525-4542, doi:http://dx.doi.org/10.15488/28.

70. Kaiser, C.; Meyer, H.; Biasi, C.; Rusalimova, O.; Barsukov, P.; Richter, A. Conservation of soil organic matter through cryoturbation in arctic soils in Siberia. J. Geophys. Res. 2007, 112, 9-17, doi:10.1029/2006JG000258.

71. Kawahigashi, M.; Kaiser, K.; Kalbitz, K.; Rodionov, A.; Guggenberger, G. Dissolved organic matter in small streams along a gradient from discontinuous to continuous permafrost. Glob. Change Biol. 2004, 10, 15761586, doi:10.1111/j.1365-2486.2004.00827.x.

72. Mergelov, N.S.; Targulian, V.O. Accumulation of organic matter in the mineral layers of permafrost-affected soils of coastal lowlands in East Siberia. Eurasian Soil Sc. 2011, 44, 249-260, doi:10.1134/S1064229311030069.

73. Oosterwoud, M.R.; Temminghoff, E.J.M.; Zee, S.E.A.T.M. van der Quantification of DOC concentrations in relation with soil properties of soils in tundra and taiga of Northern European Russia. Biogeosciences Discuss. 2010, 7, 3189-3226, doi: https://doi.org/10.5194/bgd-7-3189-2010.

74. Ernakovich, J.; Hopping, K.A.; Berdanier, A.B., Simpson, R.T.; Kachergis, E.J.; Steltzer, H.; Wallenstein, M.D. Predicted responses of arctic and alpine ecosystems to altered seasonality under climate change. Global Change Biol. 2014, 20(10), 3256-3269, doi: 10.1111/gcb.12568.

(C) 2021 by the authors. Submitted for possible open access publication under the terms and conditions of the Creative Commons Attribution (CC BY) license (http://creativecommons.org/licenses/by/4.0/). 


\section{SUPPLEMENTARY MATERIAL}
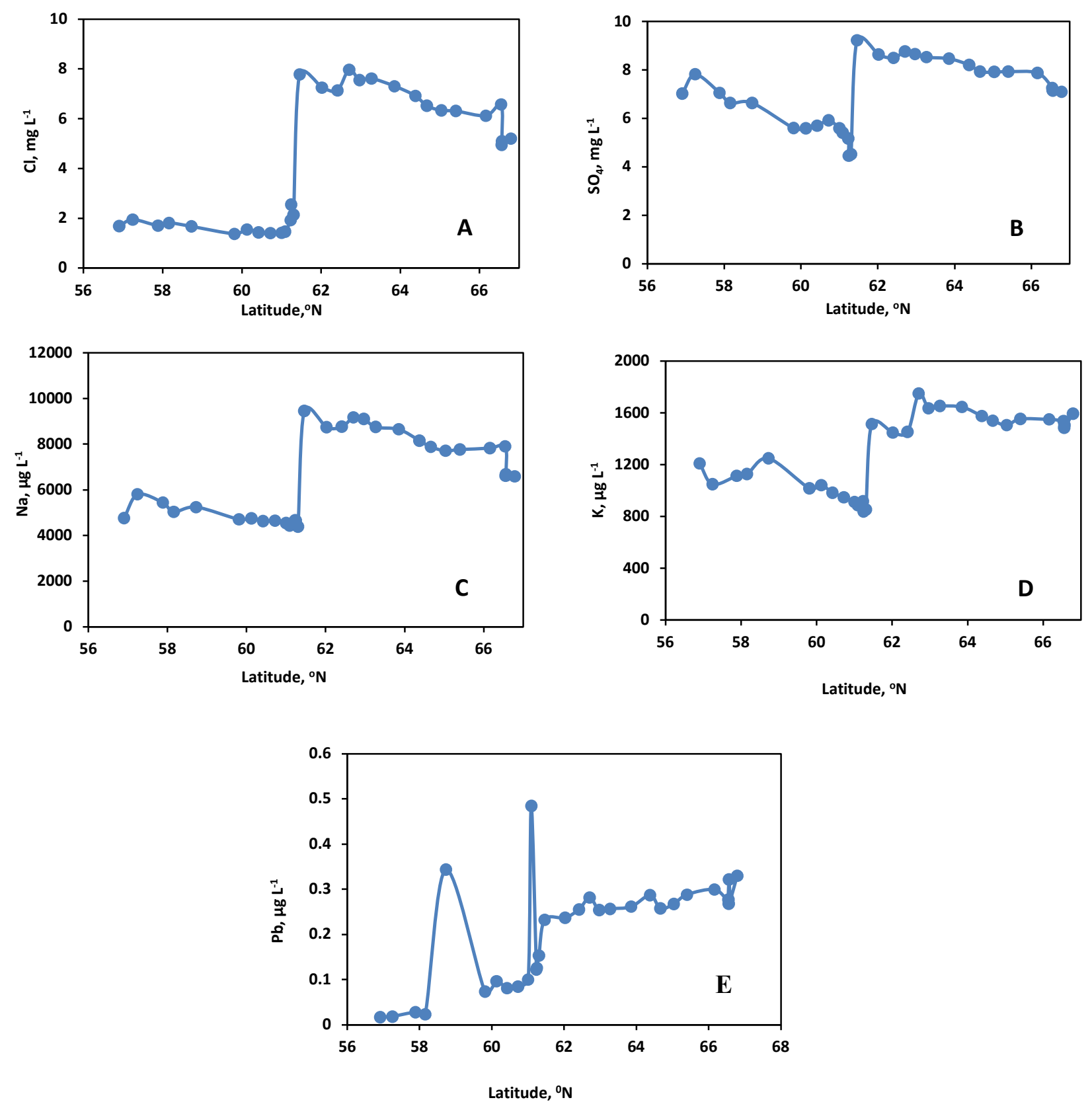

Figure S1. Latitudinal dependence of $\mathrm{Cl}(\mathrm{A}), \mathrm{SO}_{4}(\mathrm{~B}), \mathrm{Na}(\mathrm{C}), \mathrm{K}(\mathrm{D})$ and $\mathrm{Pb}(\mathrm{E})$ concentration in the main stem of the $\mathrm{Ob}$ River. A sharp increase visible at approx. $61^{\circ} \mathrm{N}$ is the confluence with the Irtysh River. 

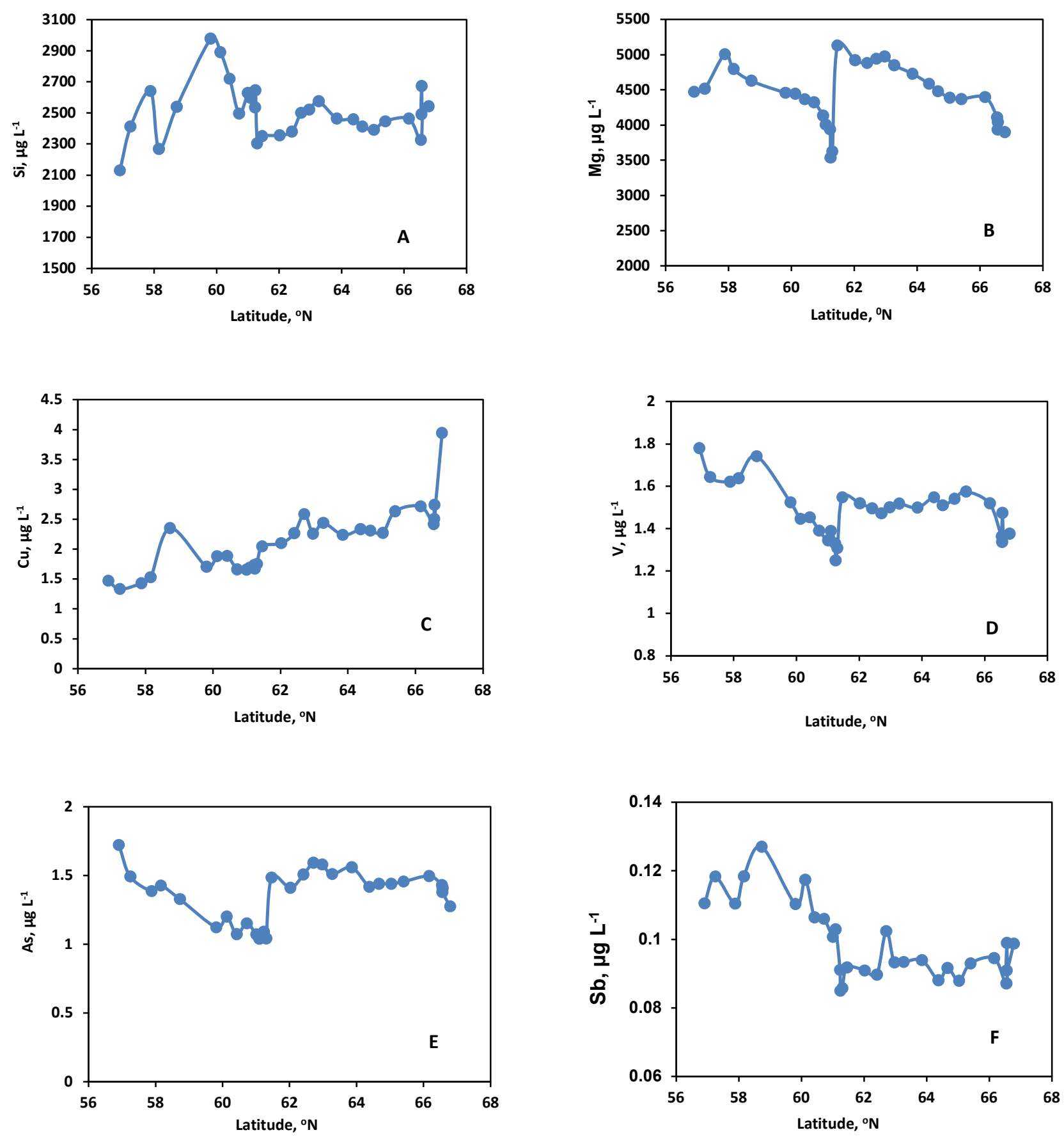

Figure S2. Main stem concentration of elements which do not show any particular pattern with latitude: $\mathrm{Si}(\mathrm{A}), \mathrm{Mg}(\mathrm{B}), \mathrm{Cu}(\mathrm{C}), \mathrm{V}(\mathrm{D}), \mathrm{As}(\mathrm{E})$ and $\mathrm{Sb}(\mathrm{E})$. 


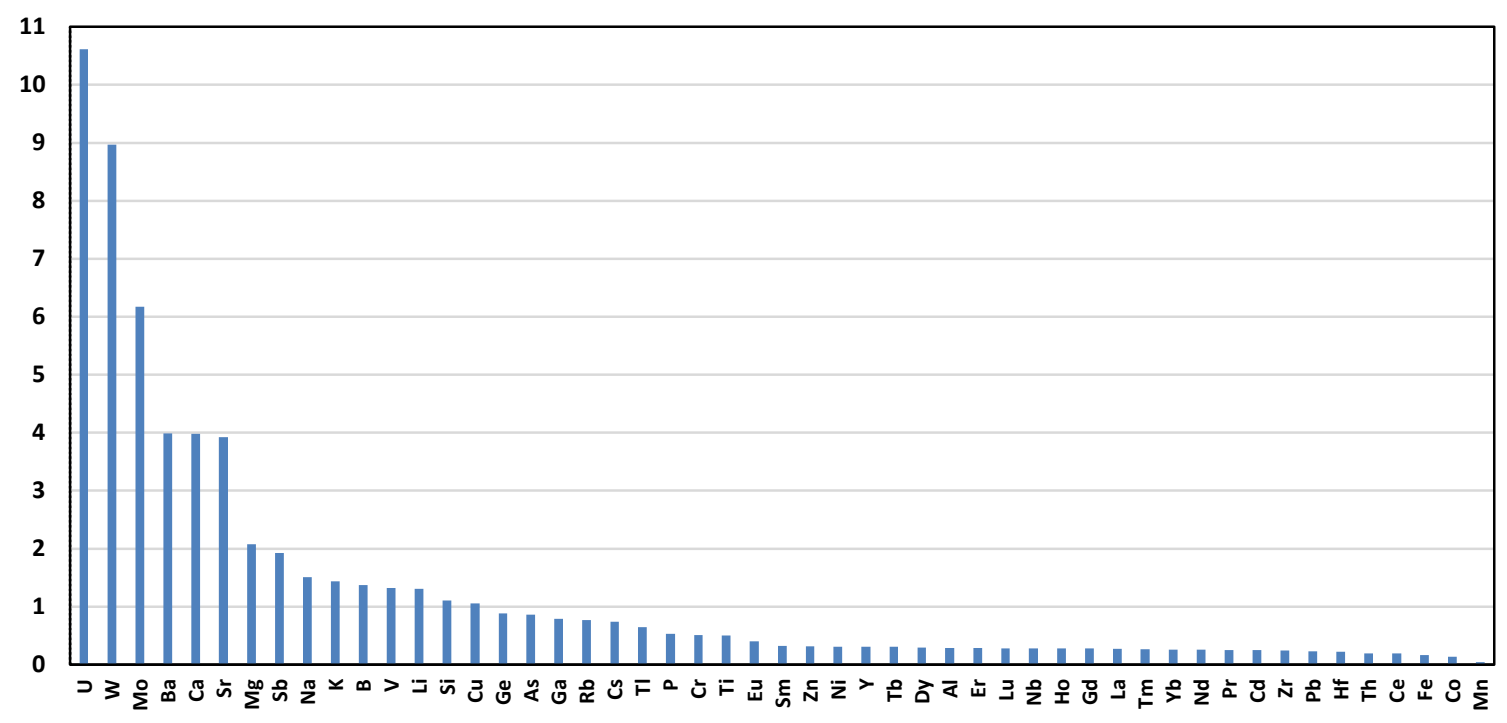

Figure S3. A histogram of elemental ratio in 2 northern tributaries (downstream of Irtysh) to 8 southern tributaries (upstream of Irtysh) of the Ob River. 


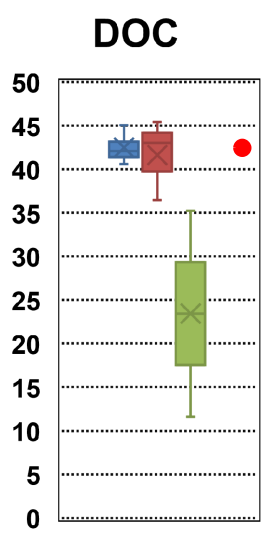

A

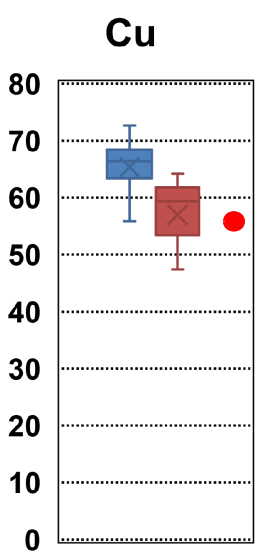

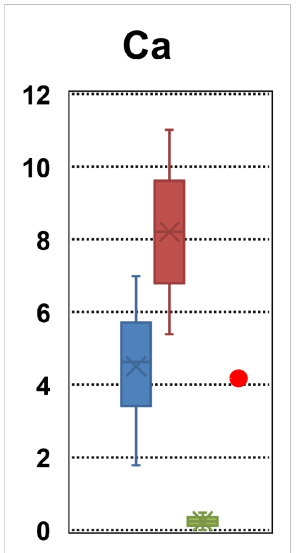

B

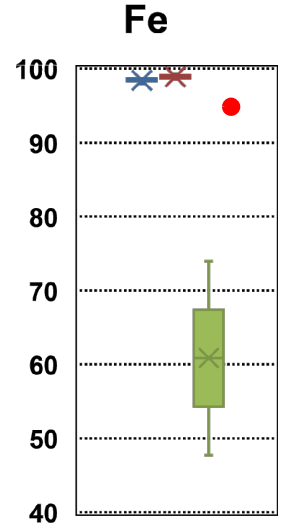

C

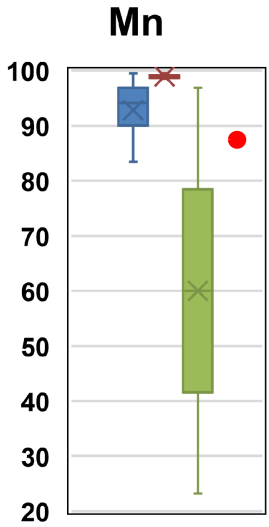

D

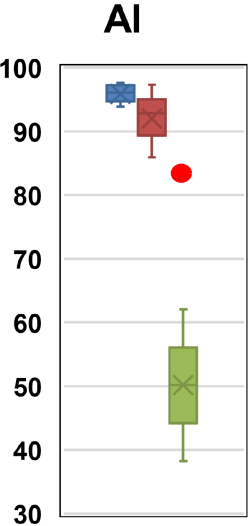

E

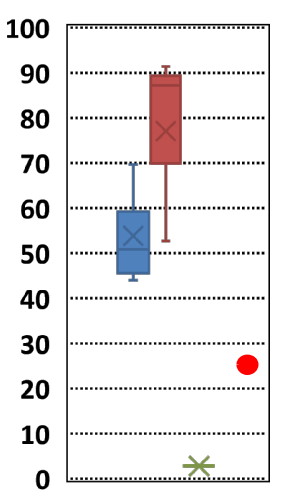

La

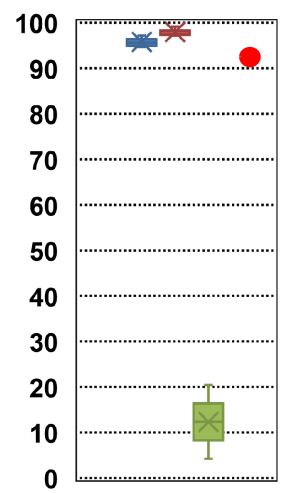

H

$\mathrm{Ob}$, main stem Tributaries of the northern part of the $\mathrm{Ob}$ Basin

Tributaries of the southern part of the $\mathrm{Ob}$ Basin

- Irtysh

Figure S4. Proportion of colloidal (1 kDa - $0.45 \mu \mathrm{m})$ fraction of DOC (A), Ca (B), Fe (C), Mn (D), Al (E), $\mathrm{Cu}(\mathrm{F}), \mathrm{U}(\mathrm{G}), \mathrm{La}(\mathrm{H})$ and Th (I) in the main stem (blue box plot column) and tributaries of the southern (blue circles) and northern (red circles) part of the Ob Basin. 

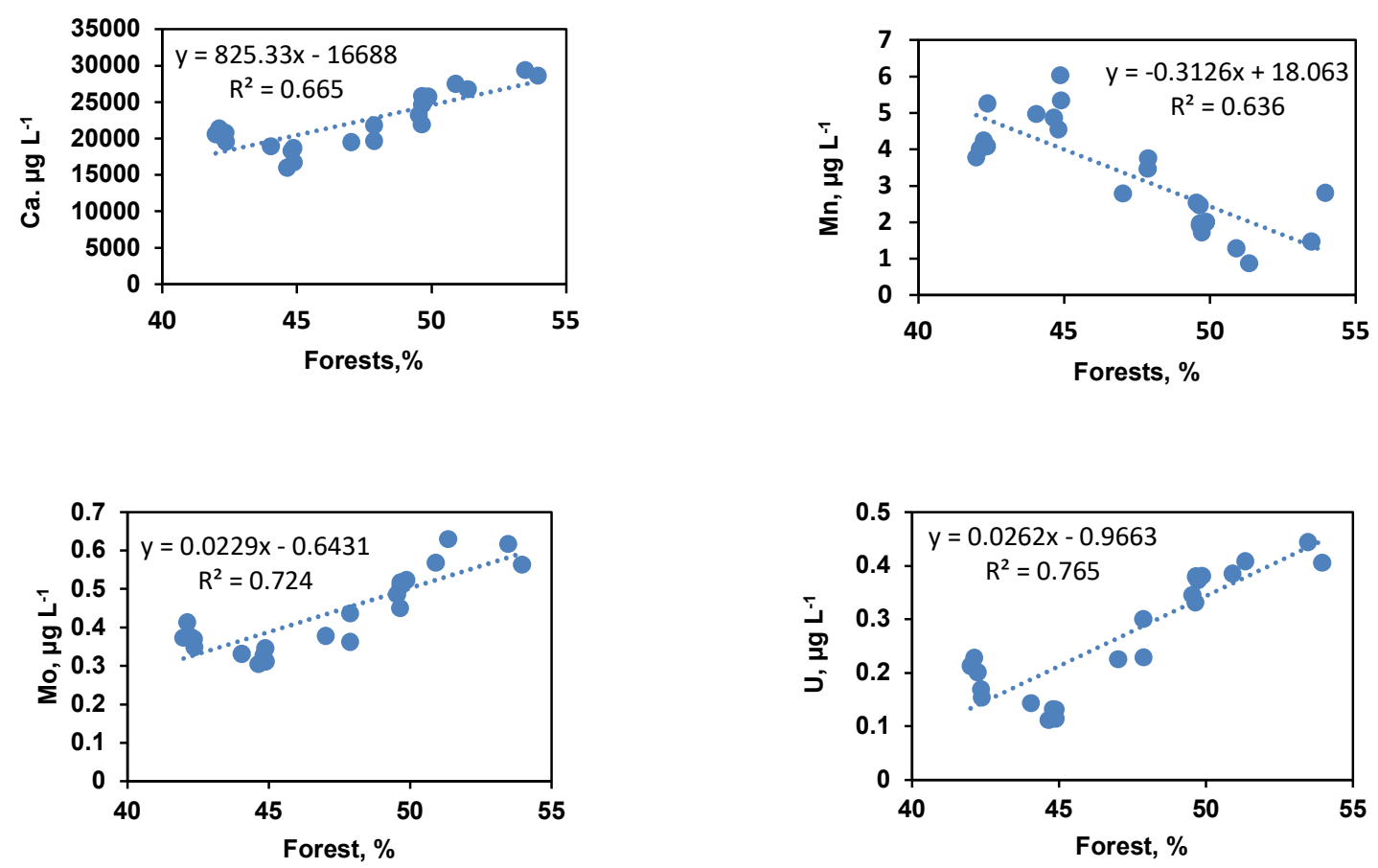

A
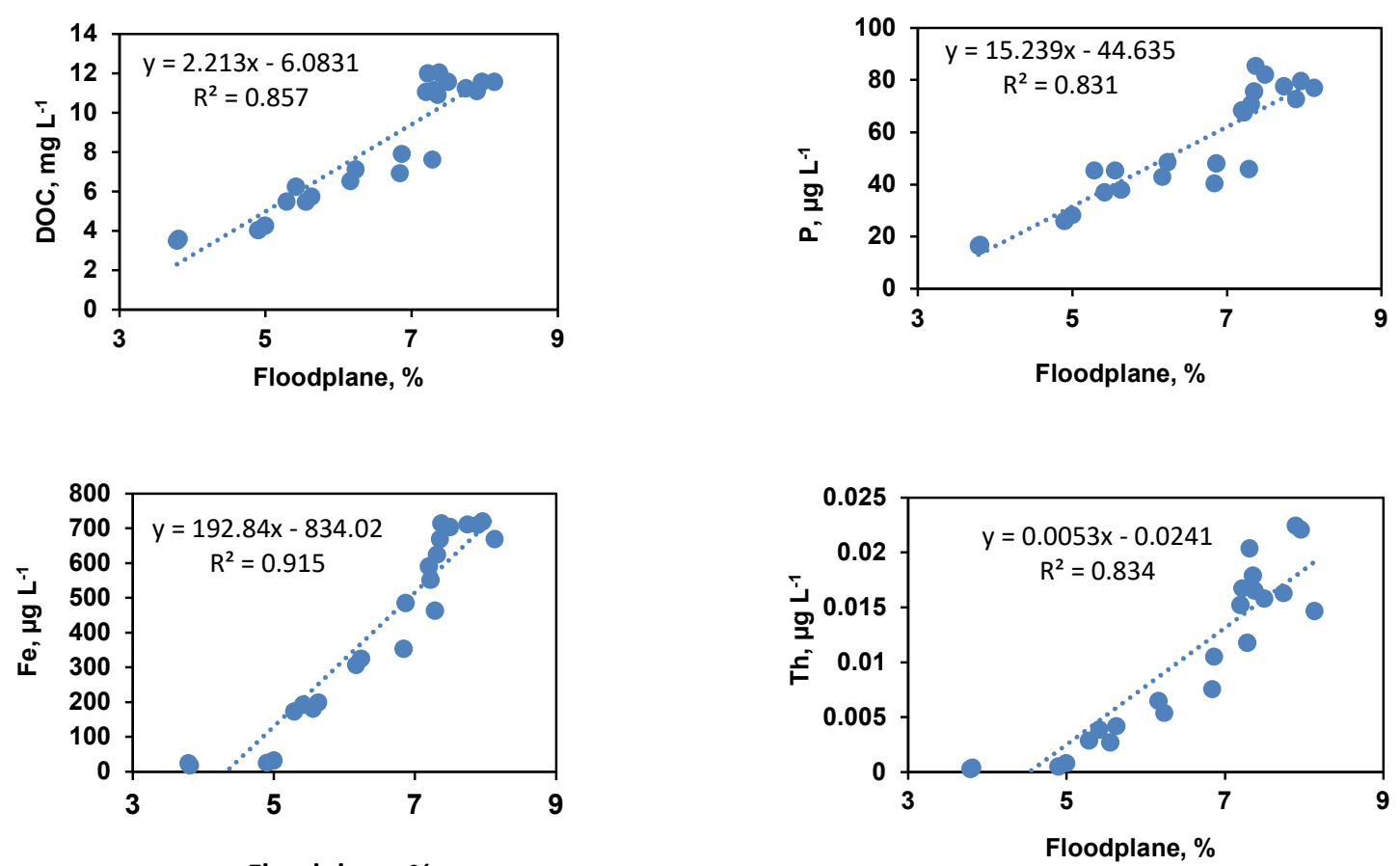

Floodplane, \%

B

Fig. S5. Examples of major and trace element concentration with landscape parameters of the Ob River main stem: A: Impact of the forest coverage on $\mathrm{Ca}, \mathrm{Mn}, \mathrm{Mo}$ and $\mathrm{U}$; B: Impact of the floodplain coverage on DOC, P, Fe and Th concentrations; C: Impact of the fluvio-glacial deposits on DOC, Al, Fe and La concentrations. 

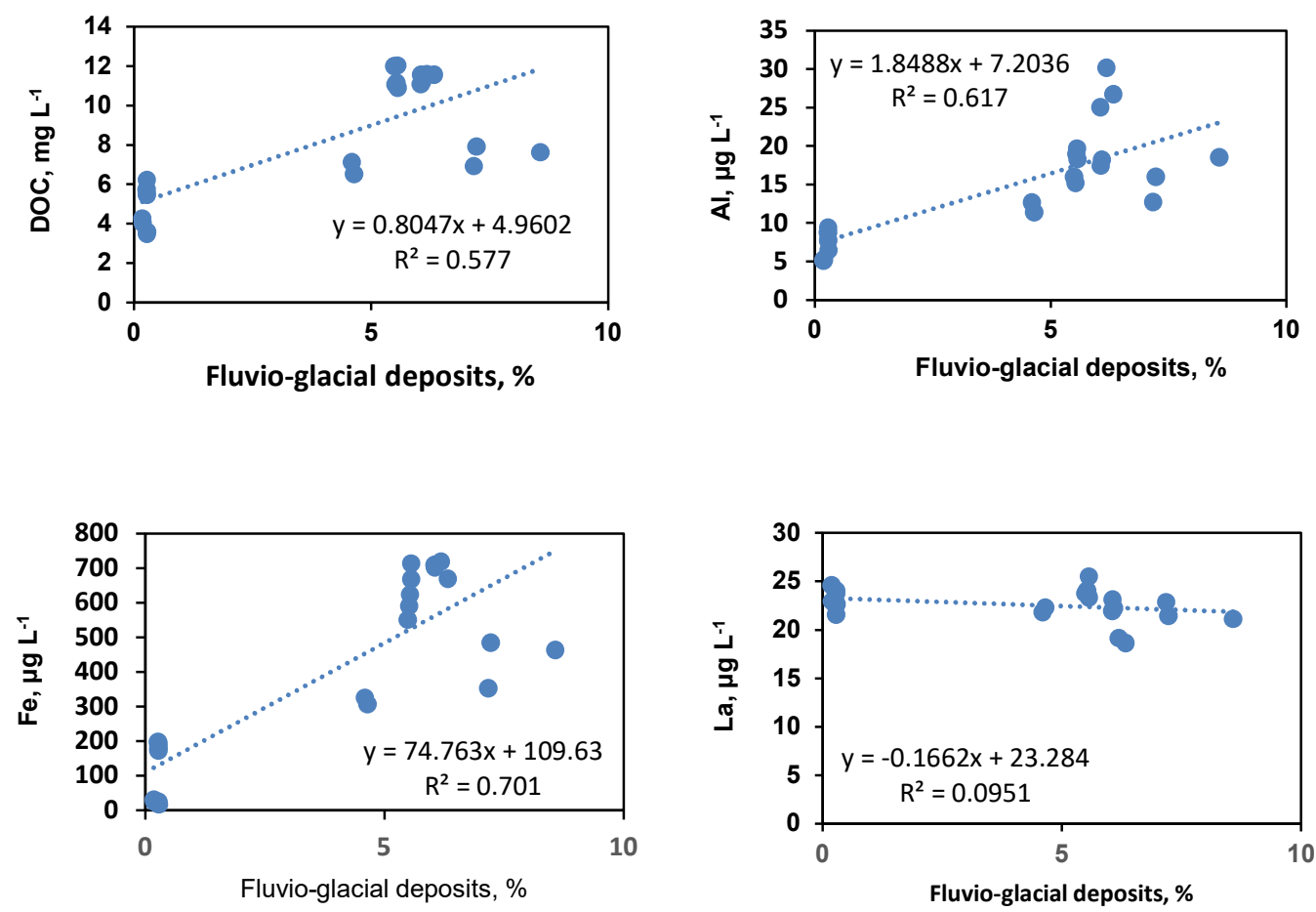

C

Fig. S5, continued. Examples of major and trace element concentration with landscape parameters of the Ob River main stem: C: Impact of the fluvio-glacial deposits on DOC, Al, Fe and La concentrations. 


\section{Ob River main stem}

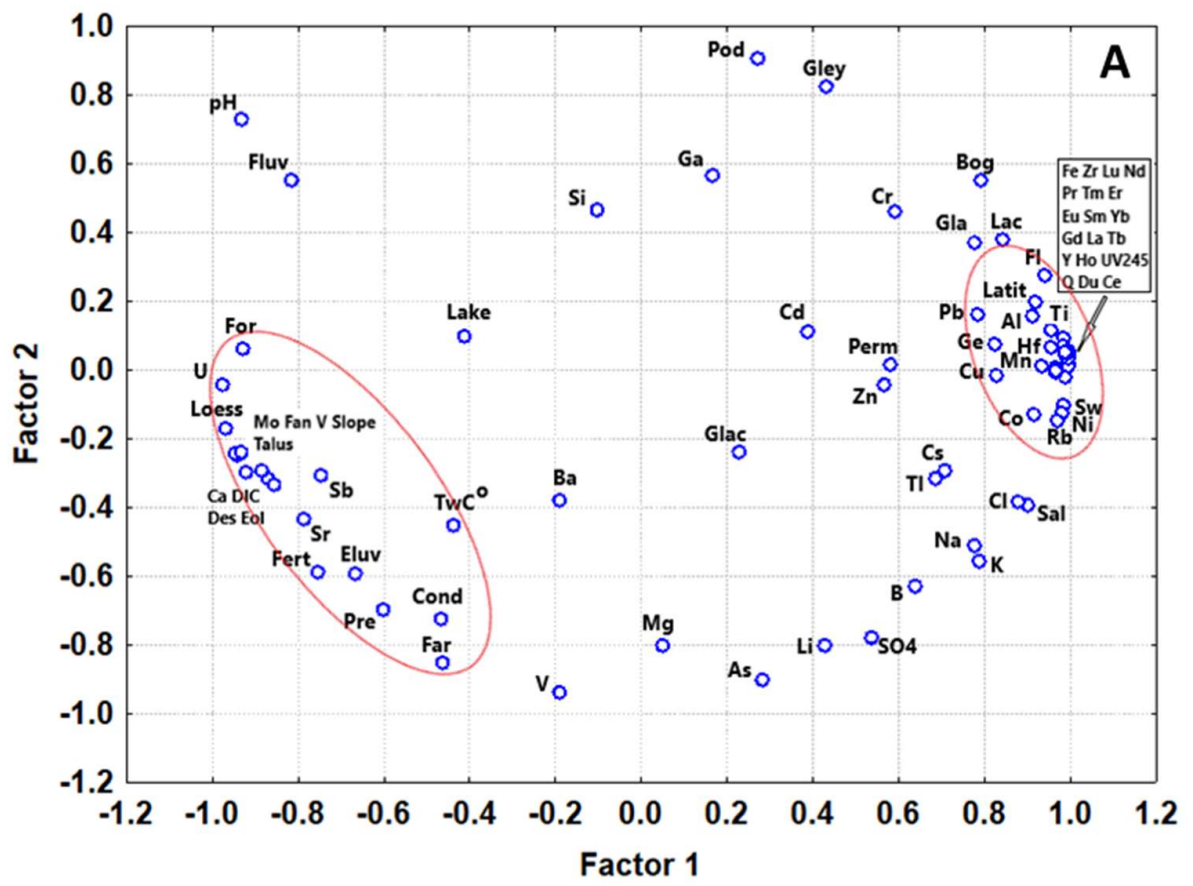

\section{Tributaries}

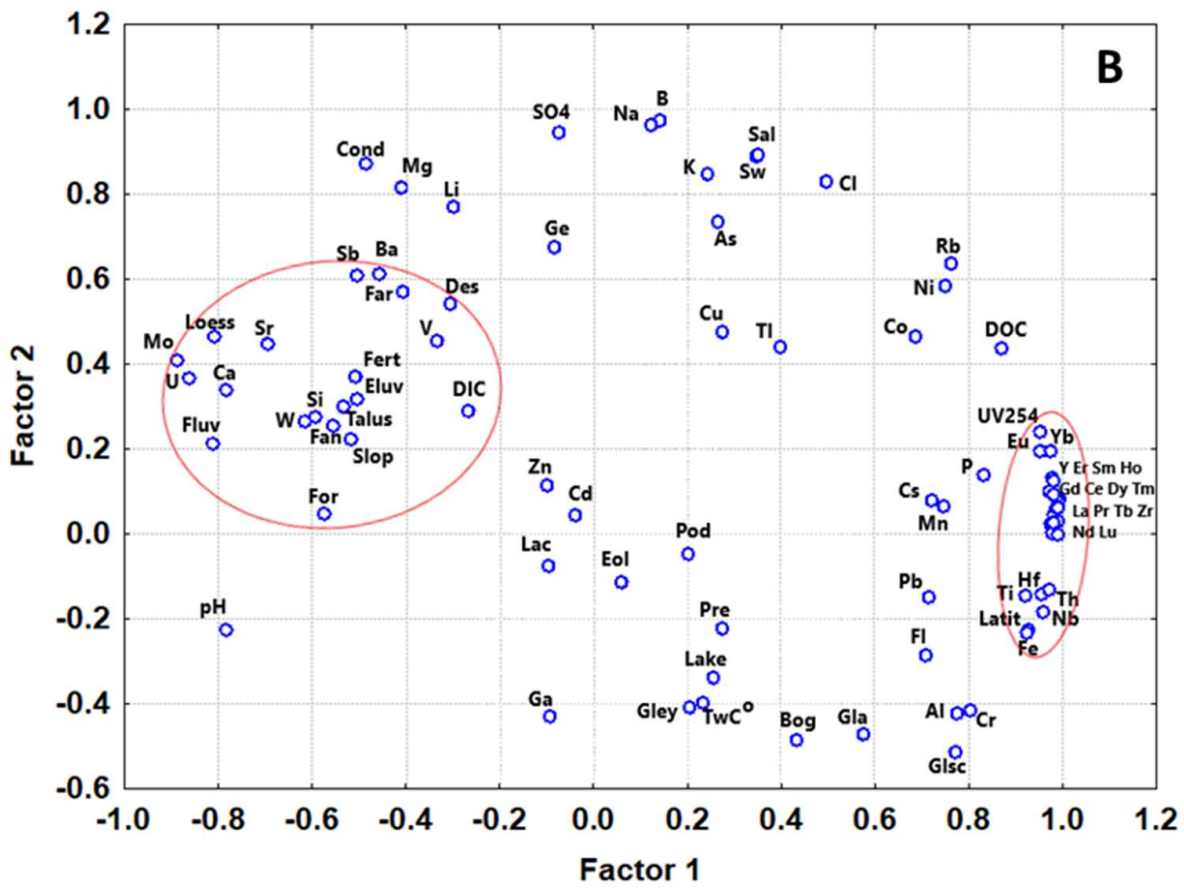

Fig. S6. Results of PCA treatment of the solute data and watershed characteristics for the Ob River main stem (a) and tributaries (b). See Fig. 7 for abbreviation of landscape parameters. 
Table S1. List of sampled sites at the main stem of the Ob River and its tributaries.

\begin{tabular}{|c|c|c|c|c|c|}
\hline Name & Number on the map & Descriptions, km & $\mathbf{N}$ & E & date \\
\hline Ob's g1 & 1 & 0 & 66.788694 & 69.143972 & 08.07.16, $21: 37$ \\
\hline Ob's g2 & 2 & 74.241 & 66.554056 & 67.839944 & 09.07.16, 11:50 \\
\hline Ob's 1 & 3 & 120.2 & 66.561925 & 67.032767 & 10.07 .2016 \\
\hline Ob's g3 & 4 & 153.8 & 66.544861 & 66.511833 & 13.07.16, $11: 30$ \\
\hline Ob's 2 & 5 & 209.7 & 66.158222 & 65.763806 & 13.07.16, $19: 00$ \\
\hline Ob's 3 & 6 & 299.7 & 65.4005 & 65.641667 & $14.07 .16,0: 28$ \\
\hline Ob's g4 & 7 & 344.9 & 65.034722 & 65.240833 & $14.07 .16,07: 48$ \\
\hline Ob's g5 & 8 & 408.6 & 64.664889 & 65.613806 & 14.07.16, 19:06 \\
\hline Ob's 4 & 9 & 452.4 & 64.378278 & 65.904444 & $15.07 .16,00: 10$ \\
\hline Ob's p4 & 10 & 527.3 & 63.852222 & 65.368917 & $15.07 .16,07: 30$ \\
\hline Ob's 5 & 11 & 610.2 & 63.269361 & 64.991528 & $15.07 .16,15: 10$ \\
\hline Ob's 6 & 12 & 648.4 & 62.968083 & 65.069278 & $15.07 .16,20: 26$ \\
\hline Ob's p5 & 13 & 687.5 & 62.7064 & 65.508883 & $16.07 .16,0: 45$ \\
\hline Ob's 7 & 14 & 744.4 & 62.411503 & 66.333239 & 16.07.16, 19:15 \\
\hline Ob's g6 & 15 & 821.2 & 62.022069 & 67.369903 & $17.07 .16,1: 22$ \\
\hline Ob's 8 & 16 & 909.0 & 61.461306 & 68.224083 & $17.07 .16,8: 00$ \\
\hline Ob's 9 & 17 & 1149.2 & 61.302833 & 71.286006 & 18.07.16, 8:03 \\
\hline Ob's 10 & 18 & 1253.9 & 61.243361 & 72.849944 & $18.07 .16,19: 27$ \\
\hline Ob's 11 & 19 & 1291.9 & 61.232167 & 73.538694 & 19.07.16, 0:25 \\
\hline Ob's 12 & 20 & 1419.9 & 61.09325 & 75.326528 & $19.07 .16,8: 00$ \\
\hline Ob's 13 & 21 & 1469.9 & 61.004361 & 76.085556 & 19.07.16, 13:15 \\
\hline Ob's 14 & 22 & 1550.6 & 60.720639 & 77.114083 & $19.07 .16,23: 13$ \\
\hline Ob's 15 & 23 & 1624.8 & 60.420694 & 77.978444 & $20.07 .16,5: 25$ \\
\hline Ob's 16 & 24 & 1702.0 & 60.124361 & 78.915167 & $20.07 .16,12: 06$ \\
\hline Ob's 17 & 25 & 1752.4 & 59.811222 & 79.116 & $20.07 .16,17: 51$ \\
\hline Ob's 18 & 26 & 2185.3 & 58.159194 & 82.941139 & $22.07 .16,15: 15$ \\
\hline Ob's 19 & 27 & 2230.4 & 57.883861 & 83.345361 & $22.07 .16,19: 15$ \\
\hline Ob's 20 & 28 & 2361.7 & 57.245944 & 84.348944 & $23.07 .16,07: 23$ \\
\hline Ob's 21 & 29 & 2410.2 & 56.906833 & 84.448892 & $23.07 .16,12: 51$ \\
\hline Ob's p1 & p_1 (Pasaydeyakha) & 0 & 67.709 & 72.904389 & 06.07 .2016 \\
\hline Ob's p2 & p_2 (Poluy) & 291.0 & 66.522917 & 66.599611 & $10.07 .16,20: 53$ \\
\hline Ob's p3 & p_3 (Pitljar) & 397.0 & 65.771694 & 65.510778 & $13.07 .16,22: 20$ \\
\hline Ob's p6 & p_4 (Irtysh) & 975.7 & 61.067947 & 68.929806 & $17.07 .16,17: 22$ \\
\hline Ob's p7 & p_5 (Nazym) & 1172.0 & 61.193594 & 68.922253 & $17.07 .16,19: 21$ \\
\hline Ob's p8 & p_6 (Ljamin) & 1172.0 & 61.280639 & 71.792972 & $18.07 .16,11: 39$ \\
\hline Ob's p11 & p_7 (Tym) & 1623.0 & 59.431417 & 80.02025 & 21.07.16, 03:09 \\
\hline Ob's p10 & p_8 (Vasjugan) & 1257.0 & 59.121222 & 80.744258 & $21.07 .16,11: 31$ \\
\hline Ob's p12 & p_9 (Kopilovskaja Ket') & 1369.0 & 58.911256 & 81.559931 & $21.07 .16,20: 00$ \\
\hline Ob's g7 & p_10 (Parabel') & 2189.0 & 58.727083 & 81.573639 & $21.07 .16,23: 33$ \\
\hline Ob's p13 & p_11 (Chulym) & 2542.0 & 57.729083 & 83.822494 & $23.07 .16,01: 00$ \\
\hline Ob's p14 & p_12 (Tom') & 2677.0 & 56.795861 & 84.530528 & $23.07 .16,12: 00$ \\
\hline
\end{tabular}


Table S2. A: Main landscape parameters (\% of the watershed coverage) of the tributaries and several key points at the Ob River main stem.

\begin{tabular}{|c|c|c|c|c|c|c|c|c|c|c|c|c|c|}
\hline $\begin{array}{l}\text { Sampling } \\
\text { point }\end{array}$ & latitude & $\begin{array}{l}\text { catchment } \\
\text { area. } \mathrm{km}^{2}\end{array}$ & Q. $\mathrm{m}^{3} / \mathrm{s}$ & Forests & Bogs & Lakes & Floodplain & Farmland & Permafrost & Podzol & $\begin{array}{l}\text { Gley } \\
\text { soils }\end{array}$ & $\begin{array}{l}\text { Saline } \\
\text { soils }\end{array}$ & $\begin{array}{l}\text { Fertile } \\
\text { soil }\end{array}$ \\
\hline g1 & 66.7887 & 2479211 & 31683 & 45 & 20 & 0.02 & 8.13 & 19 & 1.99 & 10.97 & 5.77 & 1.73 & 18.92 \\
\hline 1 & 66.5619 & 2450170 & 30835 & 45 & 20 & 0.00 & 7.96 & 19 & 1.25 & 11.05 & 5.83 & 1.76 & 19.14 \\
\hline 2 & 66.1582 & 2416527 & 30050 & 45 & 19 & 0.01 & 7.89 & 19 & 0.75 & 11.04 & 5.50 & 1.78 & 19.41 \\
\hline 3 & 65.4005 & 2399324 & 29616 & 45 & 19 & 0.00 & 7.74 & 19 & 0.62 & 11.00 & 5.34 & 1.79 & 19.55 \\
\hline 4 & 64.3783 & 2360079 & 28625 & 44 & 19 & 0.00 & 7.50 & 20 & 0.43 & 10.66 & 4.96 & 1.82 & 19.87 \\
\hline 5 & 63.2694 & 2222409 & 25151 & 42 & 19 & 0.00 & 7.38 & 21 & 0.03 & 11.32 & 5.14 & 1.93 & 21.10 \\
\hline 6 & 62.9806 & 2220366 & 25099 & 42 & 19 & 0.00 & 7.35 & 21 & 0.03 & 11.32 & 5.11 & 1.94 & 21.12 \\
\hline 7 & 62.4115 & 2210933 & 24861 & 42 & 19 & 0.00 & 7.31 & 21 & 0.06 & 11.37 & 5.13 & 1.94 & 21.21 \\
\hline g6 & 62.0221 & 2203777 & 24680 & 42 & 19 & 0.00 & 7.20 & 21 & 0.03 & 11.40 & 4.93 & 1.95 & 21.28 \\
\hline 8 & 61.4613 & 2196865 & 24506 & 42 & 19 & 0.02 & 7.22 & 21 & 0.00 & 11.43 & 4.86 & 1.96 & 21.35 \\
\hline 9 & 61.3028 & 1100150 & 18220 & 47 & 21 & 0.27 & 7.28 & 15 & 0.00 & 16.59 & 5.69 & 0.07 & 19.20 \\
\hline 10 & 61.2434 & 1059511 & 16353 & 48 & 20 & 0.01 & 6.86 & 15 & 0.00 & 17.22 & 5.91 & 0.07 & 19.94 \\
\hline 11 & 61.2322 & 1058205 & 16295 & 48 & 20 & 0.37 & 6.84 & 15 & 0.00 & 17.22 & 5.88 & 0.07 & 19.97 \\
\hline 12 & 61.0933 & 963155 & 12046 & 50 & 17 & 0.00 & 6.24 & 17 & 0.00 & 15.36 & 6.03 & 0.08 & 21.94 \\
\hline 13 & 61.0044 & 951873 & 11542 & 50 & 17 & 0.50 & 6.16 & 17 & 0.00 & 14.88 & 6.03 & 0.08 & 22.20 \\
\hline 14 & 60.7206 & 873109 & 8021 & 50 & 15 & 0.01 & 5.63 & 19 & 0.00 & 12.40 & 5.95 & 0.09 & 24.20 \\
\hline 15 & 60.4207 & 865715 & 7730 & 50 & 14 & 0.03 & 5.55 & 19 & 0.00 & 12.09 & 5.91 & 0.09 & 24.40 \\
\hline 16 & 60.1244 & 853949 & 7607 & 50 & 14 & 0.05 & 5.42 & 19 & 0.00 & 11.48 & 5.98 & 0.09 & 24.74 \\
\hline 17 & 59.8112 & 846169 & 7538 & 50 & 14 & 0.22 & 5.29 & 19 & 0.00 & 11.25 & 6.04 & 0.09 & 24.97 \\
\hline 18 & 58.1592 & 547112 & 5763 & 54 & 3 & 0.01 & 5.00 & 30 & 0.00 & 5.13 & 3.77 & 0.14 & 38.62 \\
\hline 19 & 57.8839 & 518674 & 5464 & 53 & 2 & 0.05 & 4.90 & 31 & 0.00 & 5.30 & 1.71 & 0.15 & 40.73 \\
\hline 20 & 57.2459 & 360677 & 3799 & 51 & 1 & 0.00 & 3.79 & 37 & 0.00 & 5.78 & 1.99 & 0.20 & 44.33 \\
\hline 21 & 56.9068 & 344424 & 3628 & 51 & 0 & 0.77 & 3.81 & 39 & 0.00 & 6.05 & 1.53 & 0.21 & 45.62 \\
\hline Tom' & 56.7958 & 74581 & 702 & 61 & 0 & 0.04 & 2 & 38 & 0.00 & 0.74 & 0.00 & 0.11 & 84.36 \\
\hline Thculym & 57.7291 & 133600 & 628 & 66 & 2 & 0.17 & 8 & 23 & 0.00 & 2.83 & 0.00 & 0.04 & 37.28 \\
\hline Parabel' & 58.7271 & 24600 & 90 & 58 & 38 & 0.37 & 4 & 0 & 0.00 & 2.69 & 37.56 & 0.00 & 0.00 \\
\hline Vasjugan & 59.1212 & 66404 & 214 & 60 & 40 & 0.20 & 1 & 0 & 0.00 & 10.70 & 30.62 & 0.00 & 0.00 \\
\hline Tym & 59.4314 & 37366 & & 53 & 40 & 0.39 & 8 & 0 & 0.00 & 59.45 & 0.00 & 0.00 & 0.00 \\
\hline L'yamin & 61.2806 & 27400 & & 15 & 67 & 10.95 & 11 & 0 & 0.00 & 22.70 & 0.82 & 0.00 & 0.00 \\
\hline Nazym & 61.1936 & 11395 & & 57 & 30 & 1.70 & 13 & 0 & 0.00 & 26.48 & 17.39 & 0.00 & 0.00 \\
\hline Irtysh & 61.0679 & 2183722 & 5980 & 41 & 18 & 0.53 & 6.85 & 21 & 0.00 & 10.95 & 4.51 & 1.97 & 21.48 \\
\hline Poluj & 66.5229 & 20000 & 138 & 45 & 41 & 0.50 & 11 & 0 & 10.00 & 12.46 & 33.19 & 0.00 & 0.00 \\
\hline
\end{tabular}


Table S2. B: Main genetic types of Quaternary deposits, \% of the watershed. Slopewash, Desertium, and Fanalluvial deposits represent less than $2 \%$ and not listed here.

\begin{tabular}{|c|c|c|c|c|c|c|c|c|c|}
\hline & $\begin{array}{c}\text { Pre- } \\
\text { Quaternary }\end{array}$ & Loess & Glacial & Eluvial & Lacustrine & Fluvial & Talus & Fluvio-glacial & Eolian \\
\hline \multicolumn{10}{|c|}{ The Ob River main stem } \\
\hline g1 & 2.03 & 17.98 & 5.12 & 2.84 & 16.18 & 22.40 & 1.04 & 6.33 & 0.54 \\
\hline 1 & 2.04 & 18.20 & 4.97 & 2.87 & 16.16 & 22.41 & 1.05 & 6.18 & 0.55 \\
\hline 2 & 2.07 & 18.45 & 4.69 & 2.89 & 15.99 & 22.41 & 1.06 & 6.05 & 0.56 \\
\hline 3 & 2.08 & 18.58 & 4.52 & 2.90 & 15.94 & 22.36 & 1.07 & 6.09 & 0.56 \\
\hline 4 & 2.11 & 18.89 & 4.02 & 2.94 & 15.74 & 22.33 & 1.09 & 6.06 & 0.57 \\
\hline 5 & 2.16 & 20.06 & 2.13 & 2.98 & 15.73 & 22.30 & 1.16 & 5.56 & 0.60 \\
\hline 6 & 2.16 & 20.08 & 2.09 & 2.98 & 15.73 & 22.29 & 1.16 & 5.56 & 0.60 \\
\hline 7 & 2.16 & 20.16 & 1.96 & 3.00 & 15.69 & 22.27 & 1.16 & 5.54 & 0.61 \\
\hline g6 & 2.13 & 20.23 & 1.88 & 3.01 & 15.69 & 22.24 & 1.17 & 5.52 & 0.61 \\
\hline 8 & 2.11 & 20.29 & 1.88 & 3.01 & 15.64 & 22.19 & 1.17 & 5.49 & 0.61 \\
\hline 9 & 1.83 & 21.20 & 3.06 & 2.59 & 12.88 & 28.71 & 2.15 & 8.57 & 0.71 \\
\hline 10 & 1.86 & 21.71 & 2.83 & 2.69 & 12.97 & 28.82 & 2.24 & 7.22 & 0.67 \\
\hline 11 & 1.86 & 21.73 & 2.83 & 2.69 & 12.98 & 28.80 & 2.24 & 7.17 & 0.67 \\
\hline 12 & 2.04 & 22.27 & 2.23 & 2.96 & 12.66 & 29.31 & 2.46 & 4.59 & 0.64 \\
\hline 13 & 2.07 & 22.00 & 2.23 & 2.99 & 12.48 & 29.30 & 2.49 & 4.65 & 0.64 \\
\hline 14 & 2.18 & 23.43 & 1.85 & 3.26 & 12.91 & 29.68 & 2.72 & 0.27 & 0.66 \\
\hline 15 & 2.20 & 23.19 & 1.85 & 3.29 & 12.90 & 29.66 & 2.74 & 0.27 & 0.66 \\
\hline 16 & 2.23 & 22.89 & 1.88 & 3.34 & 13.03 & 29.34 & 2.78 & 0.28 & 0.67 \\
\hline 17 & 2.25 & 22.75 & 1.89 & 3.37 & 13.15 & 29.05 & 2.80 & 0.28 & 0.68 \\
\hline 18 & 3.06 & 25.77 & 2.93 & 5.21 & 5.39 & 27.23 & 4.33 & 0.18 & 0.89 \\
\hline 19 & 3.22 & 25.39 & 3.09 & 5.49 & 3.45 & 27.27 & 4.57 & 0.19 & 0.94 \\
\hline 20 & 4.15 & 25.97 & 4.40 & 4.02 & 2.83 & 26.20 & 4.94 & 0.27 & 0.83 \\
\hline 21 & 4.35 & 24.58 & 4.60 & 4.21 & 1.95 & 26.35 & 5.18 & 0.29 & 0.86 \\
\hline \multicolumn{10}{|c|}{ Tributaries } \\
\hline Tom' & 1.57 & 27.62 & 0.67 & 6.07 & 0.52 & 39.46 & 3.03 & 0.00 & 0.02 \\
\hline Tchulym & 1.37 & 33.46 & 0.13 & 10.46 & 4.13 & 31.92 & 4.40 & 0.00 & 1.41 \\
\hline Parabel' & 0.61 & 20.33 & 0.00 & 0.00 & 44.15 & 34.89 & 0.00 & 0.00 & 0.00 \\
\hline Vasjugan & 1.13 & 24.56 & 0.00 & 0.00 & 47.69 & 27.03 & 0.00 & 0.00 & 0.00 \\
\hline Tym & 0.98 & 18.47 & 0.00 & 0.00 & 33.39 & 39.05 & 0.00 & 3.69 & 0.83 \\
\hline L'yamin & 1.46 & 0.00 & 13.26 & 0.00 & 3.42 & 18.52 & 0.00 & 59.74 & 2.75 \\
\hline Nazym & 21.36 & 0.00 & 25.87 & 0.00 & 0.96 & 16.29 & 0.00 & 33.12 & 0.31 \\
\hline Irtysh & 2.02 & 20.15 & 1.70 & 3.03 & 15.05 & 21.65 & 1.18 & 5.12 & 0.61 \\
\hline Poluj & 0.00 & 0.00 & 27.28 & 0.00 & 28.05 & 21.07 & 0.00 & 23.67 & 0.00 \\
\hline
\end{tabular}




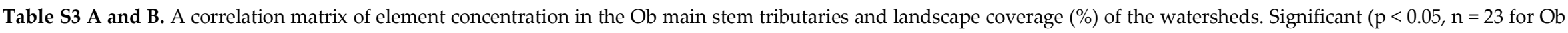
and $\mathrm{n}=9$ for tributaries)) correlations are given in red.

\section{A: Landscape and soil characteristics}

\begin{tabular}{|c|c|c|c|c|c|c|c|c|c|c|c|}
\hline & Latitude & Forest & Bogs & Lakes & Floodplain & Farmland & Permafrost & Podzol & Gley soil & $\begin{array}{l}\text { Saline } \\
\text { soil }\end{array}$ & $\begin{array}{l}\begin{array}{l}\text { Fertile } \\
\text { soil }\end{array} \\
\text { a }\end{array}$ \\
\hline S.C. & -0.69 & 0.34 & -0.53 & 0.01 & -0.69 & 0.57 & -0.43 & -0.62 & -0.44 & 0.29 & 0.54 \\
\hline $\mathrm{pH}$ & -0.85 & 0.74 & -0.04 & 0.56 & -0.56 & -0.56 & -0.81 & 0.33 & 0.37 & -0.74 & 0.14 \\
\hline $\mathrm{UV}_{254}$ & 0.93 & -0.80 & 0.51 & -0.28 & 0.75 & -0.19 & 0.73 & 0.31 & 0.18 & 0.39 & -0.56 \\
\hline $\mathrm{Cl}$ & 0.66 & -0.75 & 0.23 & -0.40 & 0.42 & 0.29 & 0.61 & -0.05 & -0.25 & 0.69 & -0.24 \\
\hline $\mathrm{SO}_{4}$ & 0.10 & $\begin{array}{l}-0.30 \\
\end{array}$ & -0.35 & -0.52 & -0.09 & 0.73 & 0.34 & -0.61 & -0.52 & 0.83 & 0.27 \\
\hline $\mathrm{DOC}$ & 0.88 & $\begin{array}{l}-0.80 \\
\end{array}$ & $\begin{array}{l}0.48 \\
\end{array}$ & -0.28 & 0.73 & $\begin{array}{l}-0.12 \\
\end{array}$ & 0.67 & 0.29 & 0.11 & 0.43 & $\begin{array}{l}-0.51 \\
\end{array}$ \\
\hline DIC & -0.76 & 0.48 & -0.41 & 0.17 & -0.80 & 0.21 & -0.61 & -0.28 & -0.13 & -0.06 & 0.46 \\
\hline $\mathrm{Li}$ & -0.01 & -0.18 & -0.30 & -0.43 & -0.06 & 0.62 & 0.25 & -0.48 & -0.57 & 0.69 & 0.22 \\
\hline B & 0.18 & -0.28 & $\begin{array}{c}-0.07 \\
\end{array}$ & -0.32 & 0.22 & 0.49 & 0.42 & -0.44 & -0.49 & 0.61 & -0.01 \\
\hline $\mathrm{Na}$ & 0.24 & -0.33 & -0.10 & -0.42 & 0.17 & 0.57 & 0.49 & -0.48 & -0.47 & 0.71 & 0.04 \\
\hline $\mathrm{Mg}$ & -0.39 & 0.11 & -0.42 & -0.16 & -0.29 & 0.63 & -0.14 & -0.55 & -0.60 & 0.44 & 0.40 \\
\hline $\mathrm{Al}$ & 0.90 & -0.64 & 0.54 & -0.27 & 0.76 & $\begin{array}{l}-0.29 \\
\end{array}$ & 0.74 & 0.43 & 0.21 & 0.21 & -0.59 \\
\hline$\overline{\mathrm{Si}}$ & -0.29 & 0.31 & -0.18 & 0.07 & -0.18 & -0.07 & $\begin{array}{l}-0.20 \\
\end{array}$ & -0.12 & 0.03 & -0.19 & 0.14 \\
\hline $\mathrm{P}$ & 0.86 & -0.69 & 0.42 & -0.35 & 0.78 & -0.13 & 0.76 & 0.24 & 0.11 & 0.39 & -0.50 \\
\hline $\mathrm{K}$ & 0.39 & -0.42 & -0.01 & -0.44 & 0.25 & 0.40 & 0.57 & -0.41 & -0.26 & 0.71 & -0.12 \\
\hline $\mathrm{Ca}$ & -0.92 & 0.68 & $\begin{array}{l}-0.48 \\
\end{array}$ & 0.31 & \begin{tabular}{c|}
-0.69 \\
\end{tabular} & 0.25 & -0.74 & -0.36 & -0.29 & -0.25 & 0.53 \\
\hline $\mathrm{Ti}$ & 0.93 & -0.70 & 0.54 & -0.31 & 0.82 & $\begin{array}{l}-0.19 \\
\end{array}$ & 0.77 & 0.33 & 0.13 & 0.33 & $\begin{array}{l}-0.59 \\
\end{array}$ \\
\hline $\mathrm{V}$ & -0.31 & 0.11 & -0.21 & -0.12 & -0.42 & 0.38 & -0.08 & -0.50 & -0.29 & 0.39 & 0.16 \\
\hline $\mathrm{Cr}$ & 0.68 & -0.49 & 0.70 & 0.05 & 0.62 & -0.53 & 0.38 & 0.63 & 0.35 & -0.08 & -0.66 \\
\hline $\mathrm{Mn}$ & 0.80 & -0.63 & 0.53 & -0.26 & 0.53 & -0.17 & 0.69 & 0.14 & 0.20 & 0.35 & -0.56 \\
\hline $\mathrm{Fe}$ & 0.97 & -0.74 & 0.56 & -0.39 & 0.80 & -0.26 & 0.81 & 0.37 & 0.22 & 0.32 & -0.61 \\
\hline Co & 0.66 & -0.50 & 0.38 & -0.27 & 0.63 & 0.02 & 0.70 & -0.09 & -0.10 & 0.35 & -0.46 \\
\hline $\mathrm{Ni}$ & 0.85 & -0.70 & 0.49 & -0.24 & 0.82 & -0.13 & 0.74 & 0.19 & 0.04 & 0.37 & -0.57 \\
\hline $\mathrm{Cu}$ & 0.71 & -0.59 & 0.52 & -0.26 & 0.58 & -0.24 & 0.62 & 0.15 & 0.10 & 0.36 & -0.62 \\
\hline $\mathrm{Zn}$ & 0.29 & 0.02 & 0.14 & -0.08 & 0.32 & 0.03 & 0.53 & -0.44 & 0.11 & 0.14 & -0.32 \\
\hline $\mathrm{Ga}$ & 0.07 & 0.09 & 0.38 & 0.23 & 0.19 & -0.45 & -0.08 & 0.47 & 0.15 & -0.43 & -0.30 \\
\hline $\mathrm{Ge}$ & 0.45 & -0.44 & 0.36 & -0.10 & 0.34 & -0.07 & 0.45 & -0.04 & -0.09 & 0.29 & -0.41 \\
\hline As & 0.11 & -0.26 & $\begin{array}{l}-0.10 \\
\end{array}$ & -0.27 & 0.02 & 0.48 & 0.36 & -0.36 & \begin{tabular}{c|}
-0.38 \\
\end{tabular} & 0.64 & 0.03 \\
\hline $\mathrm{Rb}$ & 0.86 & -0.81 & 0.46 & -0.30 & 0.70 & -0.11 & 0.67 & 0.29 & 0.04 & 0.50 & -0.51 \\
\hline $\mathrm{Sr}$ & -0.85 & 0.53 & -0.51 & 0.25 & -0.63 & 0.39 & -0.64 & -0.45 & -0.40 & -0.04 & 0.55 \\
\hline $\mathrm{Y}$ & 0.96 & $\begin{array}{l}-0.79 \\
\end{array}$ & 0.50 & -0.42 & 0.75 & -0.17 & 0.78 & 0.29 & 0.13 & 0.45 & $\begin{array}{l}-0.57 \\
\end{array}$ \\
\hline
\end{tabular}




\begin{tabular}{|c|c|c|c|c|c|c|c|c|c|c|c|}
\hline & Latitude & Forest & Bogs & Lakes & Floodplain & Farmland & Permafrost & Podzol & Gley soil & $\begin{array}{l}\text { Saline } \\
\text { soil }\end{array}$ & $\begin{array}{l}\text { Fertile } \\
\text { soil }\end{array}$ \\
\hline $\mathrm{Zr}$ & 0.96 & -0.78 & 0.54 & -0.35 & 0.76 & -0.21 & 0.81 & 0.33 & 0.19 & 0.38 & -0.59 \\
\hline $\mathrm{Nb}$ & 0.93 & -0.76 & 0.56 & -0.38 & 0.71 & -0.20 & 0.76 & 0.35 & 0.16 & 0.40 & -0.60 \\
\hline Mo & -0.94 & $\begin{array}{l}0.67 \\
\end{array}$ & -0.48 & 0.35 & -0.70 & 0.26 & -0.77 & -0.36 & -0.34 & -0.26 & 0.53 \\
\hline $\mathrm{Cd}$ & 0.40 & -0.20 & 0.08 & -0.23 & 0.33 & -0.02 & 0.56 & -0.26 & 0.22 & 0.21 & -0.24 \\
\hline $\mathrm{Sb}$ & -0.62 & 0.44 & -0.43 & 0.10 & -0.66 & 0.25 & -0.39 & -0.44 & -0.16 & 0.06 & 0.39 \\
\hline Cs & 0.61 & -0.52 & 0.30 & -0.22 & 0.50 & 0.11 & 0.68 & -0.02 & -0.11 & 0.46 & -0.37 \\
\hline $\mathrm{Ba}$ & -0.37 & 0.08 & -0.28 & -0.01 & -0.27 & 0.35 & -0.26 & -0.30 & -0.35 & 0.26 & 0.29 \\
\hline $\mathrm{La}$ & 0.97 & -0.77 & 0.50 & -0.43 & 0.76 & -0.18 & 0.78 & 0.30 & 0.16 & 0.44 & -0.58 \\
\hline $\mathrm{Ce}$ & 0.98 & -0.78 & 0.52 & $\begin{array}{l}-0.39 \\
\end{array}$ & 0.77 & -0.21 & 0.81 & 0.30 & 0.19 & 0.40 & -0.60 \\
\hline $\operatorname{Pr}$ & 0.97 & -0.77 & 0.50 & -0.43 & 0.75 & -0.18 & 0.79 & 0.31 & 0.16 & 0.44 & -0.57 \\
\hline $\mathrm{Nd}$ & 0.97 & -0.78 & 0.52 & -0.42 & 0.77 & -0.19 & 0.80 & 0.32 & 0.16 & 0.43 & -0.59 \\
\hline $\mathrm{Sm}$ & 0.95 & $\begin{array}{l}-0.79 \\
\end{array}$ & 0.49 & -0.43 & 0.74 & -0.16 & 0.77 & 0.30 & 0.14 & 0.46 & $\begin{array}{l}-0.56 \\
\end{array}$ \\
\hline $\mathrm{Eu}$ & 0.94 & -0.80 & 0.48 & -0.41 & 0.72 & -0.15 & 0.77 & 0.31 & 0.12 & 0.47 & -0.55 \\
\hline Gd & 0.97 & -0.78 & 0.52 & -0.42 & 0.76 & -0.19 & 0.80 & 0.30 & 0.16 & 0.42 & -0.58 \\
\hline $\mathrm{Tb}$ & 0.96 & -0.79 & 0.51 & -0.42 & 0.76 & -0.18 & 0.80 & 0.30 & 0.14 & 0.43 & -0.58 \\
\hline Dy & 0.96 & -0.79 & 0.50 & -0.45 & 0.74 & -0.17 & 0.79 & 0.30 & 0.14 & 0.44 & -0.57 \\
\hline Ho & 0.96 & -0.79 & 0.50 & -0.43 & 0.72 & -0.17 & 0.79 & 0.31 & 0.15 & 0.46 & -0.57 \\
\hline Er & 0.95 & -0.79 & 0.49 & -0.39 & 0.74 & -0.17 & 0.78 & 0.30 & 0.14 & 0.45 & -0.56 \\
\hline $\mathrm{Tm}$ & 0.97 & -0.79 & 0.50 & -0.37 & 0.75 & -0.19 & 0.80 & 0.28 & 0.19 & 0.42 & -0.57 \\
\hline $\mathrm{Yb}$ & 0.95 & -0.80 & 0.49 & -0.38 & 0.72 & -0.17 & 0.77 & 0.29 & 0.14 & 0.45 & -0.57 \\
\hline $\mathrm{Lu}$ & 0.96 & -0.77 & 0.54 & -0.36 & 0.76 & -0.21 & 0.79 & 0.34 & 0.19 & 0.39 & -0.59 \\
\hline $\mathrm{Hf}$ & 0.93 & -0.73 & 0.46 & -0.31 & 0.75 & -0.13 & 0.74 & 0.33 & 0.12 & 0.37 & -0.50 \\
\hline $\mathrm{W}$ & $\begin{array}{l}-0.81 \\
\end{array}$ & 0.58 & -0.34 & 0.32 & -0.78 & 0.07 & -0.73 & -0.16 & -0.11 & -0.27 & 0.40 \\
\hline $\mathrm{Tl}$ & 0.43 & -0.51 & 0.32 & -0.14 & 0.41 & 0.15 & 0.43 & 0.01 & -0.36 & 0.35 & -0.30 \\
\hline $\mathrm{Pb}$ & 0.81 & -0.60 & 0.54 & -0.26 & 0.58 & -0.35 & 0.67 & 0.19 & 0.41 & 0.20 & -0.61 \\
\hline Th & 0.95 & -0.78 & 0.53 & -0.35 & 0.73 & -0.20 & 0.76 & 0.37 & 0.21 & 0.39 & -0.56 \\
\hline $\mathrm{U}$ & -0.96 & 0.73 & -0.45 & 0.38 & -0.68 & 0.18 & -0.81 & -0.31 & -0.28 & -0.36 & 0.51 \\
\hline
\end{tabular}




\section{B: Main genetic types of Quaternary deposits}

\begin{tabular}{|c|c|c|c|c|c|c|c|}
\hline & Loess & Glacial & Eluvial & Lacustrine & Fluvial & Fluvio-Glacial & Eolian \\
\hline S.C. & 0.60 & -0.64 & 0.60 & -0.10 & 0.25 & -0.82 & 0.19 \\
\hline $\mathrm{pH}$ & 0.62 & -0.32 & -0.05 & -0.56 & 0.57 & -0.39 & 0.28 \\
\hline $\mathrm{UV}_{254}$ & -0.83 & 0.38 & -0.47 & 0.54 & -0.67 & 0.76 & -0.48 \\
\hline $\mathrm{Cl}$ & -0.57 & 0.31 & -0.15 & 0.29 & -0.75 & 0.54 & -0.42 \\
\hline $\mathrm{SO} 4$ & 0.02 & -0.23 & 0.42 & 0.19 & -0.26 & -0.25 & -0.27 \\
\hline $\mathrm{DOC}$ & -0.77 & 0.29 & -0.41 & 0.50 & -0.68 & 0.70 & -0.46 \\
\hline DIC & 0.61 & -0.53 & 0.39 & -0.20 & 0.44 & -0.75 & 0.26 \\
\hline $\mathrm{Na}$ & -0.21 & -0.16 & 0.21 & 0.37 & -0.36 & -0.07 & -0.39 \\
\hline $\mathrm{Mg}$ & 0.34 & -0.63 & 0.52 & 0.06 & 0.10 & -0.62 & 0.10 \\
\hline $\mathrm{Al}$ & -0.82 & 0.56 & -0.55 & 0.35 & -0.58 & 0.85 & -0.52 \\
\hline $\mathrm{Si}$ & 0.26 & -0.56 & 0.16 & 0.15 & 0.59 & -0.42 & 0.04 \\
\hline $\mathrm{P}$ & -0.78 & 0.26 & -0.38 & 0.59 & -0.56 & 0.62 & -0.44 \\
\hline $\mathrm{K}$ & -0.35 & -0.03 & 0.07 & 0.57 & -0.41 & 0.01 & -0.27 \\
\hline $\mathrm{Ca}$ & 0.76 & -0.66 & 0.49 & -0.31 & 0.62 & -0.87 & 0.49 \\
\hline $\mathrm{Ti}$ & -0.82 & 0.37 & -0.48 & 0.53 & -0.62 & 0.75 & -0.49 \\
\hline $\mathrm{Cr}$ & -0.69 & 0.28 & -0.66 & 0.38 & -0.43 & 0.71 & -0.37 \\
\hline $\mathrm{Mn}$ & -0.67 & 0.28 & -0.47 & 0.62 & -0.65 & 0.58 & -0.57 \\
\hline $\mathrm{Fe}$ & -0.85 & 0.45 & -0.53 & 0.55 & -0.64 & 0.80 & -0.50 \\
\hline Co & -0.65 & 0.15 & -0.33 & 0.50 & -0.49 & 0.45 & -0.64 \\
\hline $\mathrm{Ni}$ & -0.81 & 0.27 & -0.43 & 0.57 & -0.58 & 0.65 & -0.46 \\
\hline $\mathrm{Cu}$ & -0.78 & 0.08 & -0.49 & 0.74 & -0.37 & 0.45 & -0.43 \\
\hline $\mathrm{Zn}$ & -0.37 & 0.21 & -0.16 & 0.51 & -0.18 & 0.08 & -0.37 \\
\hline $\mathrm{Ge}$ & -0.52 & -0.20 & -0.30 & 0.60 & -0.17 & 0.22 & -0.51 \\
\hline $\mathrm{Rb}$ & -0.81 & 0.22 & -0.41 & 0.54 & -0.62 & 0.68 & -0.45 \\
\hline $\mathrm{Sr}$ & 0.69 & -0.75 & 0.56 & -0.24 & 0.50 & -0.85 & 0.40 \\
\hline $\mathrm{Y}$ & -0.83 & 0.37 & -0.47 & 0.55 & -0.61 & 0.74 & -0.51 \\
\hline $\mathrm{Zr}$ & -0.84 & 0.41 & -0.49 & 0.56 & -0.65 & 0.76 & -0.51 \\
\hline $\mathrm{Nb}$ & -0.82 & 0.35 & -0.51 & 0.56 & -0.65 & 0.73 & -0.54 \\
\hline Mo & 0.77 & -0.65 & 0.49 & -0.38 & 0.64 & -0.84 & 0.46 \\
\hline $\mathrm{Cd}$ & -0.39 & 0.11 & -0.16 & 0.40 & -0.19 & 0.08 & -0.61 \\
\hline $\mathrm{Sb}$ & 0.46 & -0.48 & 0.37 & -0.01 & 0.49 & -0.74 & 0.10 \\
\hline $\mathrm{Cs}$ & -0.66 & 0.42 & -0.29 & 0.39 & -0.60 & 0.51 & -0.52 \\
\hline $\mathrm{Ba}$ & 0.29 & -0.73 & 0.38 & 0.13 & 0.18 & -0.54 & 0.22 \\
\hline $\mathrm{La}$ & -0.83 & 0.40 & -0.48 & 0.54 & $\begin{array}{l}-0.62 \\
\end{array}$ & 0.75 & -0.49 \\
\hline $\mathrm{Ce}$ & -0.85 & 0.44 & -0.50 & 0.57 & $\begin{array}{l}-0.63 \\
\end{array}$ & 0.77 & -0.50 \\
\hline $\operatorname{Pr}$ & -0.83 & 0.39 & -0.47 & 0.54 & -0.61 & 0.75 & -0.50 \\
\hline $\mathrm{Nd}$ & -0.84 & 0.41 & -0.49 & 0.56 & -0.63 & 0.76 & -0.48 \\
\hline $\mathrm{Sm}$ & -0.82 & 0.35 & -0.46 & 0.55 & -0.62 & 0.74 & -0.49 \\
\hline $\mathrm{Eu}$ & -0.82 & 0.34 & -0.45 & 0.54 & -0.62 & 0.72 & -0.49 \\
\hline $\mathrm{Gd}$ & -0.84 & 0.39 & -0.48 & 0.56 & -0.61 & 0.76 & -0.52 \\
\hline $\mathrm{Tb}$ & -0.84 & 0.39 & -0.48 & 0.55 & -0.62 & 0.75 & -0.50 \\
\hline Dy & -0.82 & 0.38 & -0.47 & 0.54 & -0.63 & 0.75 & -0.50 \\
\hline Ho & -0.83 & 0.39 & -0.47 & 0.55 & $\begin{array}{l}-0.62 \\
\end{array}$ & 0.75 & -0.52 \\
\hline $\mathrm{Er}$ & -0.83 & 0.35 & -0.46 & 0.55 & -0.62 & 0.74 & -0.50 \\
\hline $\mathrm{Tm}$ & -0.84 & 0.41 & -0.47 & 0.55 & -0.63 & 0.76 & -0.52 \\
\hline $\mathrm{Yb}$ & -0.83 & 0.39 & -0.48 & 0.55 & -0.62 & 0.75 & -0.51 \\
\hline $\mathrm{Lu}$ & -0.84 & 0.38 & -0.49 & 0.56 & -0.63 & 0.76 & -0.52 \\
\hline $\mathrm{Hf}$ & -0.80 & 0.50 & -0.42 & 0.42 & -0.67 & 0.78 & -0.48 \\
\hline $\mathrm{W}$ & 0.61 & -0.44 & 0.28 & -0.33 & 0.56 & -0.66 & 0.33 \\
\hline $\mathrm{Pb}$ & -0.75 & 0.29 & -0.56 & 0.60 & -0.44 & 0.57 & -0.63 \\
\hline Th & -0.82 & 0.38 & -0.47 & 0.53 & -0.67 & 0.75 & -0.52 \\
\hline $\mathrm{U}$ & 0.78 & -0.63 & 0.45 & -0.40 & 0.68 & -0.83 & 0.51 \\
\hline
\end{tabular}


Table S4. Proportion of colloidal fraction of elements in the Ob River downstream of Irtysh (4 points) and 7 tributaries. Elements not listed in this table (Li, B, Si, Cl, DIC...) exhibited less than 5-10\% of colloids in all studied samples.

\begin{tabular}{|c|c|c|c|c|c|c|c|c|c|c|}
\hline & $\begin{array}{l}\text { p-1 (Pasay- } \\
\text { deyakha) }\end{array}$ & $2\left(\mathrm{Ob}^{\prime}\right)$ & $\begin{array}{l}\mathrm{p}-2 \\
\text { (Poluy) }\end{array}$ & $\begin{array}{l}\text { p-3 } \\
\text { (Pitljar) }\end{array}$ & $8\left(\mathrm{Ob}^{\prime}\right)$ & $10\left(\mathrm{Ob}^{\prime}\right)$ & $11\left(\mathrm{Ob}^{\prime}\right)$ & $\begin{array}{l}\mathrm{p}-4 \\
\text { (Irtysh) }\end{array}$ & $\begin{array}{l}\text { p-9 } \\
(\text { Ket') }\end{array}$ & $\begin{array}{l}\text { p-12 } \\
\text { (Tom') }\end{array}$ \\
\hline DOC & 43 & 43 & 45 & 36 & 41 & 45 & 42 & 42 & 12 & 35 \\
\hline $\mathrm{Al}$ & 86 & 95 & 93 & 97 & 98 & 97 & 94 & 79 & 62 & 38 \\
\hline $\mathrm{P}$ & 98 & 98 & 87 & 94 & 84 & 85 & 93 & 74 & 41 & 78 \\
\hline $\mathrm{Ca}$ & nd & 7 & 11 & 5 & 5 & 2 & 4 & 4 & 0 & 0 \\
\hline $\mathrm{Ti}$ & 71 & 73 & 79 & 78 & 74 & 79 & 78 & 60 & 34 & 9 \\
\hline $\mathrm{V}$ & 76 & 74 & 68 & 58 & 65 & 61 & 64 & 36 & 11 & 11 \\
\hline $\mathrm{Cr}$ & 60 & 54 & 61 & 59 & 46 & 55 & 64 & 15 & 27 & nd \\
\hline $\mathrm{Mn}$ & 99 & 92 & 99 & 100 & 100 & 83 & 96 & 99 & 23 & 97 \\
\hline $\mathrm{Fe}$ & 99 & 99 & 99 & 99 & 99 & 98 & 98 & 96 & 74 & 48 \\
\hline $\mathrm{Co}$ & 92 & 68 & 84 & 69 & 65 & 67 & 64 & 85 & 15 & 47 \\
\hline $\mathrm{Ni}$ & 41 & 51 & 76 & 54 & 49 & 51 & 47 & 46 & 31 & 14 \\
\hline $\mathrm{Cu}$ & 47 & 66 & 59 & 64 & 56 & 73 & 67 & 55 & nd & nd \\
\hline $\mathrm{Zn}$ & 92 & nd & 96 & 67 & 83 & 77 & 47 & 92 & nd & nd \\
\hline $\mathrm{Ga}$ & 86 & nd & nd & 87 & 8 & 68 & 84 & 85 & 47 & 12 \\
\hline $\mathrm{Ge}$ & 14 & 0 & 11 & 13 & 0 & 12 & 1 & 16 & nd & 0 \\
\hline As & 56 & 43 & 37 & 39 & 47 & 44 & 36 & 22 & 9 & 0 \\
\hline $\mathrm{Y}$ & 97 & 96 & 96 & 95 & 95 & 95 & 94 & 89 & 76 & 73 \\
\hline $\mathrm{Zr}$ & 99 & 96 & 99 & 98 & 98 & 98 & 98 & 95 & 93 & 89 \\
\hline $\mathrm{Nb}$ & nd & 51 & 84 & 96 & 96 & 94 & 89 & 60 & 23 & nd \\
\hline Mo & 8 & 1 & 0 & 4 & 10 & 1 & 6 & 4 & 0 & 0 \\
\hline $\mathrm{Cd}$ & 78 & nd & 85 & 38 & 43 & nd & 25 & 29 & nd & nd \\
\hline $\mathrm{Sb}$ & 0 & 0 & 21 & 26 & 19 & 16 & 12 & 17 & 0 & 2 \\
\hline Cs & nd & $<10$ & 36 & 43 & 54 & 46 & 33 & 13 & nd & nd \\
\hline $\mathrm{Ba}$ & 0 & 17 & 35 & 12 & 14 & 13 & 12 & 13 & 0 & 1 \\
\hline $\mathrm{La}$ & 99 & 95 & 97 & 97 & 97 & 96 & 95 & 91 & 4 & 20 \\
\hline $\mathrm{Ce}$ & 99 & 97 & 98 & 99 & 99 & 99 & 98 & 97 & 71 & 63 \\
\hline $\operatorname{Pr}$ & 99 & 98 & 98 & 98 & 98 & 98 & 97 & 95 & 86 & 88 \\
\hline $\mathrm{Nd}$ & 99 & 98 & 98 & 98 & 97 & 98 & 97 & 94 & 78 & 84 \\
\hline $\mathrm{Sm}$ & 98 & 97 & 96 & 97 & 98 & 96 & 95 & 96 & 80 & 92 \\
\hline $\mathrm{Eu}$ & 97 & 91 & 97 & 85 & 85 & 88 & 88 & 82 & 52 & 23 \\
\hline $\mathrm{Gd}$ & 99 & 97 & 97 & 97 & 97 & 97 & 96 & 94 & 68 & 80 \\
\hline $\mathrm{Tb}$ & 99 & 97 & 97 & 97 & 95 & 97 & 97 & 94 & 76 & 77 \\
\hline Dy & 98 & 97 & 97 & 97 & 96 & 96 & 96 & 95 & 78 & 86 \\
\hline Ho & 98 & 98 & 97 & 97 & 97 & 95 & 96 & 90 & 85 & 89 \\
\hline Er & 97 & 97 & 95 & 96 & 95 & 96 & 96 & 91 & 69 & 61 \\
\hline $\mathrm{Tm}$ & 96 & 94 & 92 & 95 & 97 & 99 & 92 & 86 & 78 & 51 \\
\hline $\mathrm{Yb}$ & 96 & 96 & 95 & 96 & 94 & 95 & 91 & 89 & 54 & 74 \\
\hline $\mathrm{Lu}$ & 93 & 98 & 94 & 92 & 93 & 92 & 90 & 84 & 69 & 45 \\
\hline $\mathrm{Hf}$ & 98 & 97 & 99 & 92 & 88 & 94 & 96 & 88 & 68 & 75 \\
\hline $\mathrm{W}$ & nd & 0 & 43 & 36 & 48 & 37 & 17 & 19 & 4 & 3 \\
\hline $\mathrm{Tl}$ & 44 & 0 & 67 & 30 & 26 & 11 & 0 & nd & 5 & 13 \\
\hline $\mathrm{Pb}$ & 99 & 98 & 99 & 100 & 100 & 99 & 96 & 95 & 25 & nd \\
\hline Th & 94 & 99 & 96 & 98 & 97 & 98 & 98 & 97 & 86 & 98 \\
\hline $\mathrm{U}$ & 87 & 70 & 91 & 53 & 56 & 46 & 44 & 25 & 3 & 3 \\
\hline
\end{tabular}

